\title{
The Effect of Hydraulic Conditions in Barbotage Reactors on Aeration Efficiency
}

\author{
Sebastian Kujawiak ${ }^{1}$, Małgorzata Makowska ${ }^{1}$ and Jakub Mazurkiewicz ${ }^{2, *(D)}$ \\ 1 Department of Hydraulic and Sanitary Engineering, Poznań University of Life Sciences, \\ 60-649 Poznań, Poland; sebastian.kujawiak@up.poznan.pl (S.K.); mmak@up.poznan.pl (M.M.) \\ 2 Institute of Biosystems Engineering, Poznań University of Life Sciences, 60-627 Poznań, Poland \\ * Correspondence: jakub.mazurkiewicz@up.poznan.pl; Tel.: +48-695-360-520
}

Received: 8 January 2020; Accepted: 29 February 2020; Published: 6 March 2020

\begin{abstract}
Barbotage reactors such as airlift reactors (ALR) and bubble column reactors (BCR), due to their two-phase flow systems, were investigated in many research papers. In their basic design variants, they are typically used to lift, mix, and aerate liquids, while, when equipped with additional elements in hybrid variants, their individual properties, i.e., lifting, mixing, and aeration of liquids, can significantly change with the same reactor geometry. The object of this study was to develop a hybrid barbotage reactor in various structural design variants. The structure consisted of a barbotage column of $50 \mathrm{~mm}$ in diameter, used to transport a water-air mixture outside the reactor (so-called external loop). The installation was additionally equipped with a nozzle in order to improve mixture aeration and circulation efficiency. The nozzle was mounted at various heights of the column pump segment. Additionally, the reactor was equipped with s moving bed in two variants ( $20 \%$ and $40 \%$ reactor capacity) in order to determine its effect on the mixture aeration and circulation conditions. Based on the measurement results, aeration curves were prepared for various structural design and column packing variants of the reactor. Properties of the two-phase mixture were determined for both parts-ALR and BCR. Technological and energy parameters of the aeration process were calculated, and the results obtained for the individual structural design variants were compared. It was found that, for the most advantageous design, in terms of aeration efficiency, the aeration nozzle should be placed in the mid-length of the pump segment of the barbotage column, irrespective of the hybrid reactor packing rate with the moving bed. The reactor packing with the moving bed resulted in a decreased mean water velocity in the reactor. For most analyzed structural design variants, the respective packing with the moving bed had no significant effect on aeration efficiency. Only for one structural design variant did the lack of packing significantly improve oxygen levels by as much as approximately $41 \%$.
\end{abstract}

Keywords: airlift; barbotage reactor; moving bed; two-phase flow; aeration efficiency

\section{Introduction}

Various factors influence water aeration processes, both directly and indirectly. Oxygen solubility in water depends mainly on water temperature and the intensity of mixing, rather than atmospheric pressure and salinity [1-3]. An increase in water temperature causes a significant decrease in the amount of oxygen dissolved in water. According to Fick's equation, a larger concentration gradient of oxygen dissolved in water between the saturation concentration and the current concentration denotes a higher oxygenation capacity. In addition, an increase in circulation (mixing) intensity supports aeration and oxygen transfer $[4,5]$.

The term barbotage refers to the flow of many gas bubbles through the liquid layer. This phenomenon is found in airlift reactors (ALR), airlift pumps (ALP), bubble column reactors (BCR), etc. 
If the systems are placed in a tank with additional elements promoting circulation and/or with a filling material in the form of large specific surface area profiles, they may be the main components of an ALR, providing appropriate conditions for the removal of contaminants and periodic transport of the treated liquid [6-8].

Although many sources present characteristics of two-phase flow and describe this phenomenon using mathematical models $[3,9,10]$, the available literature presents limited information on research concerning liquid aeration efficiency in airlift reactors and bubble columns, particularly those retrofitted with additional circulation promoting elements and/or with a filling material increasing the transfer of oxygen to the liquid [11]. Therefore, the need arises not only for a theoretical analysis of barbotage, but also the effects of such a system, i.e., hybrid barbotage reactors (HBR).

Although the literature presents a relatively abundant body of research results, hybrid barbotage reactors were not extensively investigated. It is advisable to focus primarily on the interactions between the phases, which, in reality, are closely interdependent $[5,12,13]$, and on the effect of the system size on the results.

Unfortunately, experimental studies on multi-phase flows are relatively difficult to conduct, as they are connected with the dynamics in turbulent flows [14]. The main problems here are related to the phenomena of large spatial and time scales [15]. Moreover, the used apparatus is burdened with its own limitations for the precision of measurement when assessing the location and velocity of particles and individual phases in the three-dimensional space within a given time point. Recently, research tools dedicated, e.g., to studies on multi-phase flows such as DNS (direct numerical simulations) were developed $[16,17]$. In those tools, turbulent flows are typically modeled applying Euler's method by solving incompressible Navier-Stokes equations, while the transfer of energy adjusted to scale is executed taking into consideration Kolmogorov theory [18,19]. In turn, the development of numerical techniques in problem solving based on the multi-scale approach was proposed by Andersson et al. [20] and Grew et al. [21]. Review papers on the subject present descriptions of studies in various time and length scales, starting from atoms and molecules through single devices up to complete technological lines of entire systems [22]. The description of these phenomena is facilitated by the development of computational tools such as computational fluid dynamics (CFD), providing an analysis of mass, momentum, and energy transport, as well as evaluation efficiency of the process equipment within the length scale from $10^{-5}$ to $10 \mathrm{~m}$. The CFD technique is based on the continuity theorem, which assumes that the equations of continuum mechanics may be applied to systems with a molecular structure. The phenomena of mass, momentum, and energy transport are described by non-linear, differential equations supplemented with unequivocal conditions, including boundary conditions, designed to ensure an unequivocal solution [23]. A numerical solution consists of the discretization of a differential problem, producing a system of nonlinear algebraic equations, for many years constituting an important research subject in fluid mechanics [24].

Four theories are applied to describe the mechanism of gas transfer: film, penetration, surface renewal, and film-surface renewal, thus facilitating certain model simplifications [25]. Of these, the penetration theory is most commonly used to discuss gas transfer to a liquid in bubble columns [25].

Many different proposals are presented in the literature concerning the implementation of experimental techniques to assess $k_{L} a$. They include, e.g., the dynamic method developed by Dang et al. [26], the start-up dynamic method, the dynamic pressure method $[27,28]$, and the dynamic method for fermenter systems [29]. They all rely on measuring oxygen concentration in the reactor after a step change in the input gas.

The aim of this study was to determine the effect of structural design variants and the moving bed packing in a barbotage hybrid reactor on hydraulic conditions and aeration efficiency. The performance of a hybrid barbotage reactor was tested at two heights of an additional nozzle installed to enhance mixing and aeration processes and at varying rates of the reactor moving bed packing. 


\section{Review of Literature}

\subsection{Aeration Parameters}

In industrial and design practice, several parameters are most commonly used to characterize the effectiveness of aeration devices. These are technological parameters, such as oxygen capacity and standard oxygen transfer rate, and economic parameters, i.e., standard oxygen transfer efficiency and standard aeration efficiency described in the source texts: (ASCE Standard 1992) [30] and (German ATV 1997) [31].

Oxygenation capacity $(O C)$ determines the amount of oxygen introduced into the liquid in $\mathrm{kg}$ $\mathrm{O}_{2} / \mathrm{m}^{3} \cdot \mathrm{h}$ at the initial oxygen deficit (Equation (1)).

$$
O C=2.30310^{-3} \times c_{S}^{\prime} \times \frac{1}{t_{n}} \times \sqrt{\frac{k_{10}}{k_{r}}} \times \log \frac{c_{s}-c_{o}}{c_{S}-c_{t}},
$$

where $c_{S}^{\prime}$ is the oxygen concentration in the liquid in the state of saturation at a temperature of $10^{\circ} \mathrm{C}$, and pressure of $1013 \mathrm{hPa}\left(\mathrm{g} / \mathrm{m}^{3}\right.$; for clean water $\left.c_{s}^{\prime}=11.33 \mathrm{~g} / \mathrm{m}^{3}\right), t_{n}$ is the oxygenation time $(\mathrm{h}), k_{10}, k_{r}$ are the oxygen diffusion constants in the liquid at a temperature of $10{ }^{\circ} \mathrm{C}$ and at the temperature at which oxygenation was carried out, $c_{S}$ is the oxygen concentration in the liquid saturated at the measurement conditions $\left(\mathrm{g} / \mathrm{m}^{3}\right), c_{o}$ is the initial oxygen concentration in the liquid at the start of oxygenation $\left(\mathrm{g} / \mathrm{m}^{3}\right)$, and $c_{t}$ is the oxygen concentration in the liquid after oxygenation over time $t_{n}\left(\mathrm{~g} / \mathrm{m}^{3}\right)$.

The maximum oxygenation capacity is expressed by Equation (2).

$$
O C_{0}=26.1 \times k_{L} a \times \sqrt{\frac{k_{10}}{k_{r}}}
$$

where $k_{L} a$ is the oxygen volumetric mass transfer coefficient for temperature $\mathrm{T}\left(\mathrm{min}^{-1}\right)$.

The methodology to determine $k_{L} a$ based on measurements of dissolved oxygen concentration during the time of delivery was presented by Suschka et al. [32].

Standard oxygen transfer rate (SOTR) determines the amount of oxygen in $\mathrm{kg} \mathrm{O} / 2 / \mathrm{h}$ introduced into the liquid during the operation of the aerator (Equations (3)-(5)).

$$
\mathrm{SOTR}=k_{L} a_{20} \times c_{s, 20} \times V,
$$

where $V$ is the volume of the aeration chamber $\left(\mathrm{m}^{3}\right), c_{s, 20}$ is the oxygen concentration in the state of saturation for a temperature of $20{ }^{\circ} \mathrm{C}\left(\mathrm{g} / \mathrm{m}^{3}\right)$, and $k_{L} a 20$ is the oxygen volumetric mass transfer coefficient for $20^{\circ} \mathrm{C}\left(\mathrm{h}^{-1}\right)$.

$$
\begin{gathered}
c_{S 20}=c_{S T}\left(\frac{1}{\tau \Omega}\right), \\
k_{L} a_{20}=k_{L} a_{T} \times 1024^{(20-T)},
\end{gathered}
$$

where $c_{S T}$ is the oxygen concentration under the measurement conditions $\left(\mathrm{g} / \mathrm{m}^{3}\right), \tau$ is the temperature correction factor, equal to $c_{S T} / c_{S 20}$, where $c_{s 20}$ is the state of oxygen saturation for clean water at $20^{\circ} \mathrm{C}$ $\left(c_{\mathrm{s} 20}=9.08 \mathrm{~g} / \mathrm{m}^{3}\right), \Omega$ is the pressure correction factor, equal to $P_{b} / P_{s}$, where $P_{b}$ is barometric pressure at the measurement conditions and $P_{s}$ is the pressure value under standard conditions ( 1 atm), $k_{L} a_{T}$ is the oxygen transfer coefficient at the measurement temperature $T\left(\mathrm{~h}^{-1}\right)$, and $T$ is the temperature of measurement $\left({ }^{\circ} \mathrm{C}\right)$.

Standard oxygen transfer efficiency (SOTE) is the percentage amount of oxygen used in relation to the introduced oxygen stream (Equations (6) and (7)).

$$
\mathrm{SOTE}=\mathrm{SOTR} / W_{\mathrm{O} 2}
$$


where $W_{O 2}$ is the mass flow of oxygen $(\mathrm{kg} / \mathrm{h})$.

$$
W_{O 2}=0.2765 Q_{p},
$$

where $Q_{p}$ is the flow rate of air supplied $\left(\mathrm{m}^{3} / \mathrm{h}\right)$.

Standard aeration efficiency (SAE) determines the energy efficiency of the aeration process, expressed in $\mathrm{kg} \mathrm{O}_{2} / \mathrm{kWh}$ (Equation (8)).

$$
\mathrm{SAE}=\frac{O C \times V}{P C},
$$

where $P C$ is the energy consumption by the aerator $(\mathrm{kWh})$.

\subsection{Bubble Column Reactors}

Bubble column reactors (BCR) used as multiphase reactors, also when filled with a bed, are frequently used in various branches of industry, as well as research, to describe a number of phenomena, particularly sewage treatment, fermentation, etc. [33-35]. These reactors have several advantages in terms of their operation and maintenance, e.g., high heat and mass exchange rates, compactness, and low operation and maintenance costs [36]. A number of papers were published recently to present review studies on large-scale and multiphase flows in bubble columns [37], as well as their diverse applications [36]. The above-mentioned studies investigated parameters affecting large-scale and multiphase flows, e.g., column dimensions, internal column structure, operating conditions (i.e., pressure and temperature), the effect of surface gas velocity, the type of solid, and concentration. Many experimental studies concerned the quantification of the effect of operating conditions, physical properties of the suspension, and column dimensions on the operation of bubble columns [38].

The hydrodynamic characteristics of bubble column reactors have a considerable effect on the operation and efficiency of bubble columns [19]. Three types of flow structures are commonly observed in bubble columns: homogeneous bubble flow, heterogeneous (churn-turbulent) flow, and slug flow regime [36,37]. A turbulent flow is often observed in large-diameter columns for commercial scale production $[39,40]$. The gas-liquid mass transfer rate is lower in turbulent (heterogeneous) flow compared with homogeneous flow. The scheme of potential flow regimes in bubble columns was presented in References [37,39,41]. Liquid phase properties, such as surface tension and viscosity, as well as the column diameter, affect the transition points of the flow regime [42]. The addition of surfactants or electrolytes stabilizes the homogeneous flow regime by suppressing bubble coalescence [39]. The surfactant (e.g., salt $\mathrm{CaCl}_{2}$ ) has a dual effect on both the voidage and the regime transition; a larger concentration destabilizes the homogeneous bubble bed, while a low concentration achieves the contrary [43].

The research on large-scale bubble columns using CFD was published by several scientists in 2017. They simulated large-scale bubble columns using the Eulerian multi-fluid approach. In their research, they analyzed interfacial forces, turbulence, and coalescence and decay. These aspects were selected individually for each case. In their studies, they validated a set of closure relationships that included a pseudo-homogeneous flow regime that is associated with a wide range of bubble sizes and large spray holes used in industrial applications, i.e., on large-scale bubble columns. Researchers stated, among others, that the global and local fluid dynamics of the bubble column are reasonably predicted by using the polydisperse formulation with bubble coalescence and break-up closures. In addition, they noted that the ability to predict the global and local fluid dynamics of the bubble column is strongly associated with the participation of large and small bubbles in the void fraction profiles; furthermore, the results suggested that a new closure for the lift force is necessary in order to improve the simulation results [44].

In the same year as the previous experiments, similar ones were made using a bi-dispersed Eulerian model to account for both the stabilizing and the destabilizing effects of small and large 
bubbles. In their research [45], scientists presented simulations of the air-water flow in an annular gap bubble column of $0.24 \mathrm{~m}$ internal diameter, at air superficial velocities ranging from $0.004 \mathrm{~m} / \mathrm{s}$ to $0.225 \mathrm{~m} / \mathrm{s}$, in both flow regimes (i.e., homogeneous and heterogeneous). The researchers found that the relative amount of small bubbles in the models is particularly important, which can be determined as a result of empirical correlations or experimental data. As in the results discussed above [44], researchers stated that the bubble coalescence and break-up phenomena is important for the correct prediction of the heterogeneous flow regime.

In general, it may be concluded that gas holdup increases with an increase in gas velocity and operating pressure, while it decreases with an increase in liquid viscosity and concentration of solids $[36,37,46]$. In bubble columns, the effect of the column size on gas holdup is negligible when column diameter is greater than $0.1-0.15 \mathrm{~m}$ and its height exceeds 1-3 m; in other words, at height-to-diameter ratios greater than five [36], some studies failed to confirm it [47]. It is found that these scale-up criteria are valid for the air-water case in batch mode for "very coarse" spargers. Conversely, they are no longer important given the different liquid velocities and/or aqueous solutions of active agents and other sparger orifices [47]. At low gas velocities, the gas holdup also depends on the number, pitch, and diameter of nozzle orifices. In the case of a nozzle diameter greater than $1 \mathrm{~mm}$, the effect of the diameter declines [36]. However, there is still a lack of experimental data on large BCRs, which makes it impossible to carry out accurate validations to assess the applicability of many current flow models [37].

Another team of researchers investigated the potential use of different correlations to scale up the bubble column reactor [46]. They conducted experiments with various parameters, i.e., the scale of operation, up to 1000 times greater than the laboratory scale, and the sparger used. The tests were carried out with air and water on a pilot scale (1.6 m diameter) using a coarse bubble sparger. They confirmed that the efficiency of the bubble column reactor depends critically on the gas-liquid mass transfer coefficient; therefore, forecasting this factor as a function of design and operational conditions is essential for increasing the BCR scale. Those researchers found that existing correlations actually describe $k_{L} a$ in a wide range of $\mathrm{BCR}$ sizes, suggesting that these correlations are relatively insensitive to scale. However, they noticed that the correlations did not provide a proper description for the role of the sparger. They suggested that the role of the sparger needs to be taken into account by well-tested performance factors for a given spray device [46].

Several earlier studies (from the 1980s) concerning the injection of an air-water mixture into a cylindrical water bath through a single-hole bottom nozzle to generate a vertical turbulent bubbling jet tested many approaches to describe phase flows and bubble characteristics. Those papers presented simplified methods of correlating axial mean velocity and root-mean-square values, among other things [48-50]. Experiments on various nozzle types, including diffusers with single and multiple orifices of various diameters, on hydrodynamic properties and characteristics of air-water bubbly jets discharged at the bottom of a water chamber were presented in Reference [51]. The obtained results indicated that, for identical air and water flow velocities, the total orifice surface area, irrespective of the number of these orifices, determines the initial momentum of the bubbly jets and the jet-to-plume length scale of the flow. Those researchers introduced an integral model and obtained entrainment coefficients for each test and for various water depths, which confirmed that many bubbles may be analyzed jointly using an equivalent integer model of a single jet. Those studies provided a description of entrainment described as a function of kinematic buoyancy flux, bubble slip velocity, and distance from the source, which is similar to that given in the available literature for bubble plumes, but with different constants. The most interesting outcome of these studies was provided by the constructed model, applicable in practice, e.g., for mixing and aeration of water bodies, including the potential to increase gas transfer efficiency using multiple-orifice arrangements [51]. Experiments conducted on a larger scale using state-of-the-art measuring devices, providing much better fit of the models to actual complicated systems, were presented in several recent publications [51-53]. 
For bubble column reactors (BCR) the gas holdup in a mixture $\varepsilon_{G}$ may be established using the volumetric method based on the volume of liquid displaced by bubbles [54].

$$
\varepsilon_{G}=\frac{V_{G}}{V_{L}+V_{G}},
$$

where $V_{L}$ is the volume of liquid in the reactor $\left(\mathrm{m}^{3}\right)$, and $V_{G}$ is the volume of liquid displaced by air bubbles in the reactor $\left(\mathrm{m}^{3}\right)$.

In the literature, several hydrodynamic studies on BCR columns can be found depending on the diameter and height of the reactor, gas distribution site, superficial velocity, and column filling, e.g., in the form of tubes (with plain tube internals or pin-fin tube internals) [55]. These tests determined the gas retention degree $\varepsilon_{G}$ (gas holdup) and liquid velocity in the $u_{L}$ reactor depending on the $r / R$ parameter (the measurement of the distance relative to the reactor radius-dimensionless radial coordinate) for different measurement heights and gas velocity $\mathrm{u}_{\mathrm{G}}$ of their gas distribution site. Based on the analyses carried out in the above works, it can be concluded that on overall gas holdup for various gas distributor designs (uniform aeration, central aeration, and near-wall aeration) increases with the velocity of gas $\mathrm{u}_{\mathrm{G}}$. Fluid velocity $\mathrm{u}_{\mathrm{L}}$ and gas holdup $\varepsilon_{\mathrm{G}}$ decrease as the $\mathrm{r} / \mathrm{R}$ parameter increases [55]. In addition, overall gas holdup for various column fillings (with plain tube internals, with pin-fin tube internals) increases with gas velocity $\mathrm{u}_{\mathrm{G}}$, and the velocity of liquid $\mathrm{u}_{\mathrm{L}}$ decreases with the increase of the $r / R$ parameter and the type of column filling. Pin-fin tube internals limit the velocity of liquid $u_{L}$ in the column to the greatest extent; in some zones, it significantly hinders internal circulation [56].

The interfacial area is another important parameter especially when designing gas-liquid reactors on a larger scale. This parameter is strongly related to the unit's geometrical size, the work characteristics, and the physical and chemical properties of the gas-liquid mixture [57]. To assess a specific interfacial area based on the bubble size and gas retention, the following equation can be used:

$$
a_{s}=\frac{6 \varepsilon_{G}}{d_{s}},
$$

where $d s$ is the Sauter mean bubble diameter $(\mathrm{m})$.

For the purpose of determining the interface between bubble columns, two main methodological groups can be used-physical and chemical. Chemical methods can be used to account for interfacial area values, whereas physical measurement processes give local values [58]. Changes in the interfacial area have a significant impact on $k_{L} a$ in the bubble column reactor [59]. Assuming spherical bubbles, a specific gas-liquid interface is associated with the gas holdup, $\varepsilon_{G}$, and the Sauter mean bubble diameter, $d_{S}$, can be calculated using Equation (10).

\subsection{Airlift Reactors}

Due to their mechanism of action and the flow of the medium Airlift reactors may vary in their design [1]. In terms of the reactor bubble column modification, airlift reactors are classified into two main types, i.e., those with internal and external circulation of the medium $[1,3,60]$. Four main hydrodynamic zones may be distinguished in the airlift reactor: the riser zone, where the gas-liquid mixture rises; the downcomer zone, where a completely or partially degassed gas-liquid mixture falls; the degas zone, where the gas-liquid mixture is degassed either completely or partially; and the bottom zone [61].

Gas holdup and the oxygen transfer coefficient for airlift columns with external circulation were investigated, and the influence of physicochemical properties of liquids and column geometry on oxygen permeation was analyzed by References $[1,13]$. It is assumed that the dimensions of the reactor have a marked effect on hydrodynamics and mass transfer rates, particularly on the oxygen transfer coefficient $k_{L} a[13,62,63]$. It is generally assumed that hydrodynamics become independent of the column size only if the column diameter $(\mathrm{D})$, column height $(\mathrm{H})$, and aspect ratio $(\mathrm{H} / \mathrm{D})$ are greater than certain threshold values $[64,65]$. 
The analyses of oxygen mass transfer from the gas phase to the liquid phase for 20 different reactor geometries, as well as the dependence among three parts of the pneumatic reactor, i.e., the riser, the downcomer, and the gas-liquid separator, were conducted in relation to the total mass transfer in the reactor [66]. It was shown that the gas-liquid separator plays an important role in the reactor performance, and it needs to be considered when designing reactors. It was stated that the total volumetric mass transfer coefficient in the reactor $k_{L} a$ may be correlated with the pneumatic power of gas input per total dispersion volume (P/VD) and with the true riser superficial gas velocity [66]. In addition, it was noted that $k_{L} a$ is directly related to the P/VD with an exponent close to 1 . "Two-sparger" systems, with a gas sparger mounted a short distance from the downcomer inlet, take higher absolute values for $k_{L} a$ than single-sparger system [66].

Transport phenomena in terms of the effect of geometrical relations on gas holdup and liquid velocity and, consequently, on the gas-liquid volumetric mass transfer coefficient were investigated in a 6-L airlift bioreactor [67]. The AD/AR ratio was 0.63 , where the individual surfaces are the downcomer cross-sectional area (AD) and the riser cross-sectional area (AR). In such a water-air system, the measurements of the oxygen volumetric mass transfer coefficient $\left(k_{L} a\right)$ taken under different conditions were examined based on varying parameters such as superficial air velocity in the riser, bottom clearance, and top clearance. According to the researchers, the two latter parameters have a remarkable effect on $k_{L} a$ values. This effect results from their impact on gas holdup and liquid velocity; the surface air velocity in the vertical plane ranged from 0.0126 to $0.0440 \mathrm{~m} / \mathrm{s}$, while $k_{L} a$ ranged from 40 to $250 \mathrm{~h}^{-1}$, while gas holdup assumed values up to 0.2 . Some experimental mass transfer data of airlift loop reactors indicate that neglecting the oxygen depletion may be regarded as a reduction of the mass transfer driving force, which is closely related to the height of the reactors [68].

Based on the research results presented above, it may be generally stated that the volumetric mass transfer coefficient $k_{L} a$ increases with gas velocity, density, and pressure, while it decreases with an increase in the concentration of the solid and liquid viscosity and due to the effect of surfactants.

Loyless and Malone [10] performed aeration efficiency tests in 50-mm-diameter airlift pumps equipped with two air injection systems: fine-bubbled and thick-bubbled. Those experiments confirmed that the oxygen transfer capacity in airlift pumps amounts to $20 \%$ up to $50 \%$, being much smaller than in traditional deep aeration systems. The standard oxygen transfer rate (SOTR) increases in proportion to the amount of air supplied, inversely to the standard aeration efficiency (SAE), which decreases as a result of on increased energy consumption. It turned out that both thick and fine bubble aeration provided similar values of SOTR and SAE.

The Zuber-Findlay (Z-F) slip model for a two-phase flow makes it possible to determine basic parameters describing such flow, e.g., gas holdup $\alpha_{g}$. [69]. That model is not based on the flow velocity of individual liquid-gas phases; it is only based on the flow velocity of one phase in relation to the other phase, expressed as relative velocity (drift).

The general form of the Zuber-Findlay model is represented by Equation (11).

$$
\frac{u_{G}}{\alpha_{G}}=C_{0} \times u_{T P}+v_{d r}
$$

where $\alpha_{g}$ is the gas holdup, $C_{0}$ is the distribution parameter, $u_{T P}$ is the superficial velocity of the mixture $(\mathrm{m} / \mathrm{s}), u_{G}$ is the superficial velocity of the gas $(\mathrm{m} / \mathrm{s})$, and $v d r$ is the drift velocity $(\mathrm{m} / \mathrm{s})$.

Literature on the subject comprises numerous publications confirming the accuracy of Equation (9) [70-72].

Hibiki and Ishii [71-73] in their studies developed a set of three-dimensional constitutive equations describing the slip model in a simplified on-dimensional form of the Zuber-Findlay model. Equations describing the distribution parameter $C_{0}$ were proposed.

In order to identify the flow structure in two-phase liquid-gas flows, a toll was constructed in the form of a flow map. The map developed by Ulbrich [74] was based on the analysis of 31 maps of 
two-phase flows in vertical pipes. This map makes it possible to identify the structure of two-phase liquid-gas flows in vertical pipes.

\subsection{Influence of Moving Bed on System Aeration}

In the available body of literature, we may find several sources describing the positive effect of barbotage reactor filling on liquid aeration. Results of some research papers $[5,75]$ showed that the above-mentioned aspect is still ambiguous. Kalenik et al. [76] carried out a study on a tubular aerator filled with a moving bed of Białecki rings. Those authors showed that the efficiency of oxygenation of treated water increases with an increase in the flow of the air supplied to the system. Other kinetic studies indicate an even more important factor, i.e., biofilm diffusion in controlling the mass transfer phenomenon compared to hydraulic factors in the system [77].

Experiments carried out for conventional activated sludge (CAS) and moving bed biofilm reactors (MBBR) showed the advantage of the former in terms of the removal of organic substances and nitrogen compounds [78].

In turn, other studies compared moving bed biofilm reactors (MBBR), providing a significant carbon footprint reduction, with conventional ones (CAS), with a significant drawback noted, i.e., a low energy efficiency of aeration is observed for the use of coarse diffusers, which guarantee high reliability and low maintenance costs in relation to fine bubbles. In addition, the presence of carriers inside the reactor underlines this aspect. A $40 \%$ volume filling with biofilm carriers reduced oxygen transfer efficiency, especially when using coarse diffusers and high air flows $\left(150 \mathrm{Nm}^{3} / \mathrm{h}\right)$ [5]. In that study, oxygen transfer efficiency between the medium bubble aeration system and the fine ceramic bladder diffuser was experimentally tested, while the effect of biofilm growth on oxygen transfer was assessed as well. Several tests were carried out, including the effect of coarse and fine bubbles at different air flow rates. Additionally, the impact of carriers on aeration performance, in the case of both clean water and wastewater, was assessed in terms of the effect of bacterial growth on carriers. The main results were as follows: the presence of biomass had a positive effect on oxygen transfer efficiency, and the fine-bubble system located outside the center of a tank ensured good mixing even with no mixer being used, while the fine-bubble aeration system compared to the coarse aeration system showed no improvement in oxygen transfer efficiency. In addition, the increase in air flow had a negative effect on aeration efficiency, in contrast to the conclusions given in a study by Kalenik [76].

An important example is provided by the geometry of biofilm carriers [1,79]. A team of scientists [1] using an airlift reactor (ALR) with screw screen plates (HSP) in the vertical section intensified the gas-liquid mass transfer process. The mass transfer and mixing characteristics of the ALR unit with different HSP structures were analyzed and compared by means of gas holdup, volumetric mass transfer coefficient, bubble velocity, and mixing time as evaluation parameters. Through the optimized HSP, gas holdup and volumetric mass transfer of the reactor mass increased significantly by $38 \%-53 \%$ and $76 \%-144 \%$, respectively, when compared to the classic ALR.

The benefits of using a biofilm (on moving bed) in wastewater technology may be enhanced by improving the parameters of the most important system components. In this case, the researchers decided to optimize the structure of the carrier that affects the strength of the mold, microbial growth, and effectiveness of the treatment, taking into account the predicted conditions under which the carriers will be used [79]. Mathematical modeling was used to facilitate the selection of the optimal geometry of the carrier, so that it had sufficient capacity to carry mass and transport oxygen.

\section{Materials and Methods}

\subsection{Description of the Testing Station}

The technological test on the physical model was carried out on a laboratory installation in the university water laboratory. The schematic diagram is presented in Figure 1. 


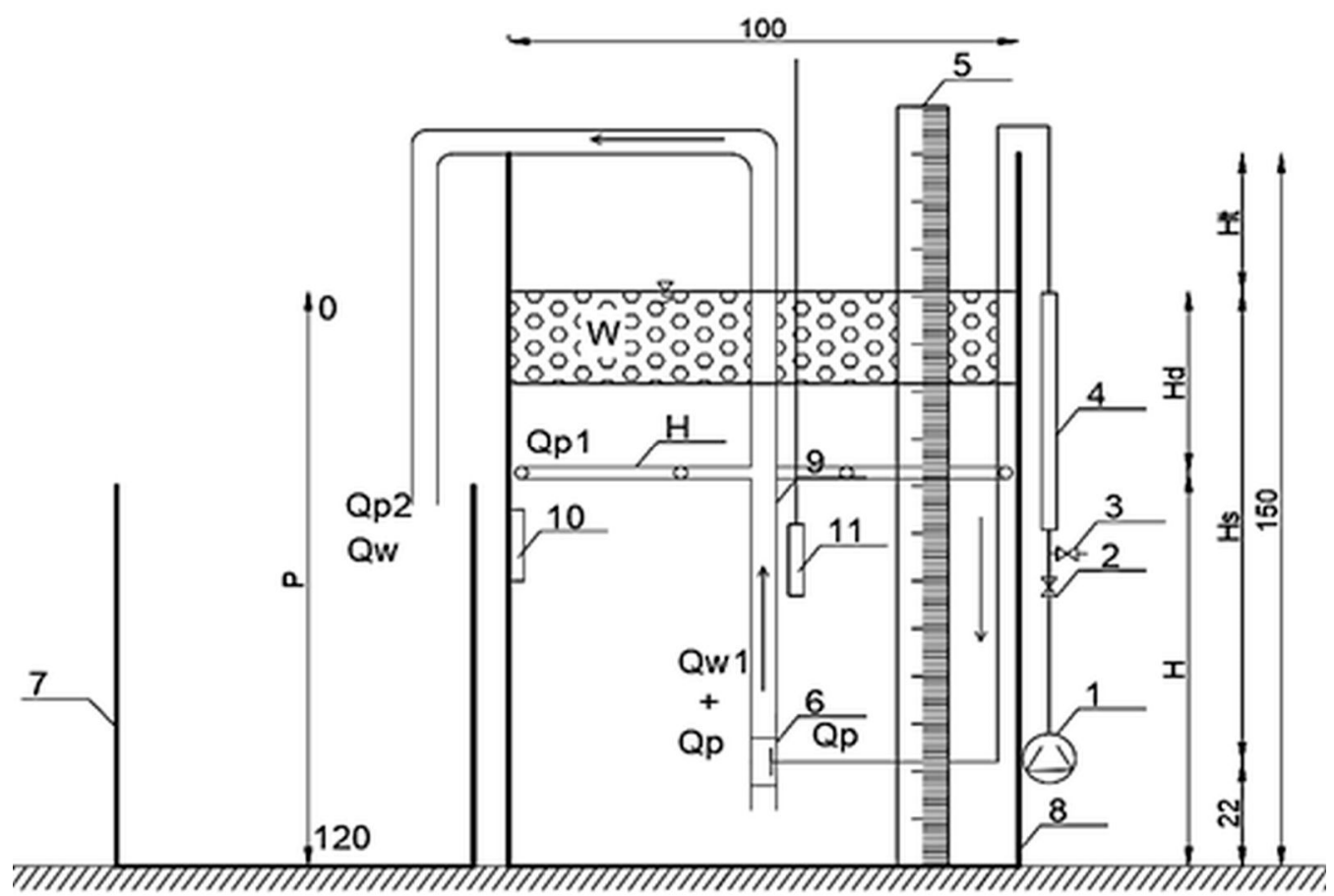

Figure 1. Scheme of the installation: 1-air blower, 2-control valve, 3-blow off valve, 4-rotameter, 5-scale, 6-diffuser, 7-recirculation tank, 8-main tank, 9-airlift pump with nozzle, 10-hydrostatic liquid level sensor, 11-liquid dissolved oxygen sensor (LDO), Qp-supply air flow rate, Qp1—flow rate of air from nozzle $\mathrm{H}, \mathrm{Qp}$ - flow rate of the exhaust airlift pump, Qw1-flow rate of water in the section 6-H, H-nozzle, Hs-immersion height, $\mathrm{cm}$, Ht-lifting height, $\mathrm{cm}$.

The primary element in the physical model was an airlift of $50 \mathrm{~mm}$ in diameter, installed in the main tank (8). The tank was a cylinder of $100 \mathrm{~cm}$ in diameter and $150 \mathrm{~cm}$ in height. In the tank axis, an airlift (9) was installed with a pipe element $(\mathrm{H})$ to ensure circulation and water aeration $H$. The pipe was a four-way piece, differing in the arm lengths $(25$ and $45 \mathrm{~cm}$ ), with nozzles of $32 \mathrm{~mm}$ in diameter. The diffusor (6), i.e., a water and air mixer, was the main element in the airlift. In view of the free inflow of water into the airlift, the inlet was mounted $22 \mathrm{~cm}$ above the tank bottom. The airlift was fed by two membrane blowers (1) arranged in a serial connection and equipped with a release valve (3) and a valve regulating the intensity of air inflow supplied to the installation (2). The amount of supplied air $Q_{p}$ was measured using a cone-and-float rotameter (4) and determined at the required level using valves $(2,3)$. The water level in the tank was measured using an analog measuring rod (5) and a hydrostatic liquid level probe coupled with a microcontroller (10).

Aeration was analyzed for six structural design variants of the reactor, differing in the location of the nozzle pipe over the tank bottom $(\mathrm{H}=34 \mathrm{~cm}$ and $\mathrm{H}=84 \mathrm{~cm})$, as well as the moving bed filling with cylindrical, goffered plastic fittings of $16 \mathrm{~mm}$ in diameter and height $(0 \%, 20 \%$, and $40 \%$ reactor volume), whose structural design variants are given in Figure 2.

The reactor was filled with fresh tap water up to the level marked on the measuring rod (5). For the $\mathrm{H} 34$ design variant, it was $84 \mathrm{~cm}$, while, for variant H84, it was $124 \mathrm{~cm}$. Each time, fresh water was subjected to 30-min aeration in order to expel contained chlorine; additionally, salinity was also measured using a salinometer, and $\mathrm{pH}$ was controlled on an ongoing basis over the course of the tests. Next, water was deoxygenated using sodium sulfate (following the ASCE guidelines) applying $\mathrm{Na}_{2} \mathrm{SO}_{3}$ at $100 \mathrm{~g} / 1000 \mathrm{dm}^{3}$ water at the initial dissolved oxygen concentration of $8 \mathrm{mg} / \mathrm{dm}^{3}$. In order to ensure adequate water and reagent mixing, a mobile impeller pump was used. After complete water deoxygenation, the blowers were turned on together with a multimeter equipped with an liquid dissolved oxygen (LDO) probe (11) placed at an adequate depth in the reactor. Measurements were 
taken at every $20 \mathrm{~cm}$ starting from the water surface level as the 0 level at five depths $\mathrm{P}$ for $\mathrm{H}=34 \mathrm{~cm}$ and at seven depths $\mathrm{P}$ for $\mathrm{H}=84 \mathrm{~cm}$ (Figure 3). The measuring probe was installed along the reactor axis, as the preliminary aeration analyses at a given level $\mathrm{P}$ showed identical oxygen concentrations irrespective of the distance from the reactor axis. Liquid dissolved oxygen concentration was measured in the water at 1-min intervals until approximately $90 \%$ saturation concentration was reached at the current water temperature. That enabled obtaining the oxygen concentration in the water at approximately $9 \mathrm{mg} / \mathrm{dm}^{3}$. Next, water was pumped out of the reactor (8) to a sewer system. After the thorough rinsing of the elements inside the reactor (8) (fittings/moving bed, structural elements), it was refilled with fresh tap water. For each structural design variant in Figure 2 and level $\mathrm{P}$, the measurements were taken in three replications applying the above methodology; thus, a total of 108 replications were made. The obtained results were averaged.
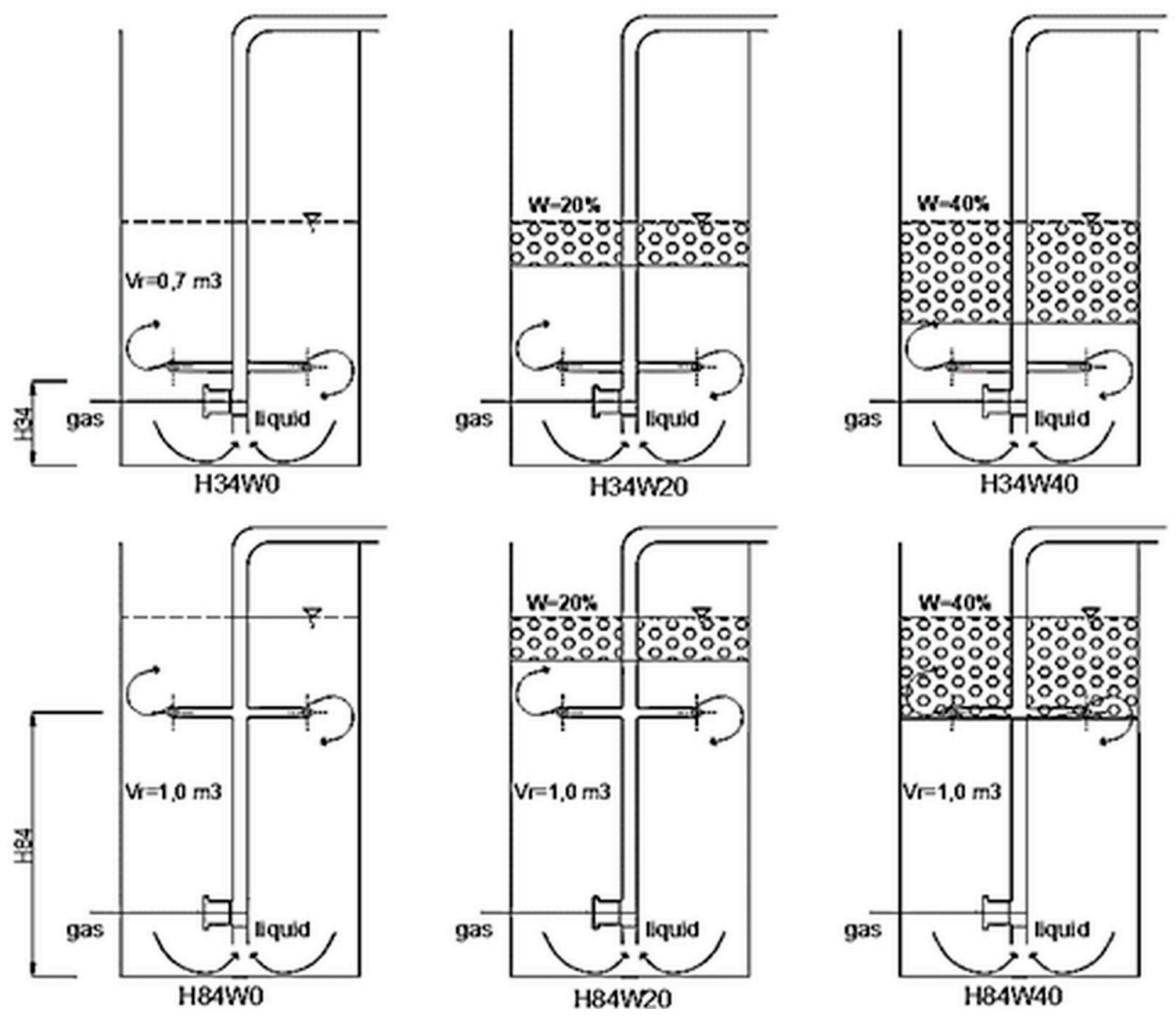

Figure 2. Structural design variants of a hybrid barbotage reactor.

Circulation velocity of the liquid in the reactor $v_{c r}$ was analyzed for two measuring points, denoted as M1 and M2, for different depths P (Figure 3). Three replications of each were made. The measurements were taken using an electromagnetic measuring probe for all six structural design variants of the hybrid barbotage reactor.

Values of flow volume intensity $Q_{p}$ and $Q_{w 1}$ at the section from the diffuser (6) to the pipe element $\mathrm{H}$ (Figure 1) were determined using an air flow meter (4) and a liquid velocity sensor (LVS), installed in front of the diffuser (6). Flow $\mathrm{Q}_{\mathrm{w} 1}$ was determined based on the value of the measured velocity of liquid inflow and the pipe diameter. Ten replications were made for each design variant $\mathrm{H}$ and $\mathrm{W}$.

The scheme of hydraulic and technological tests (aeration) is presented in Figure 3 and Figure S1 (Supplementary Materials). 


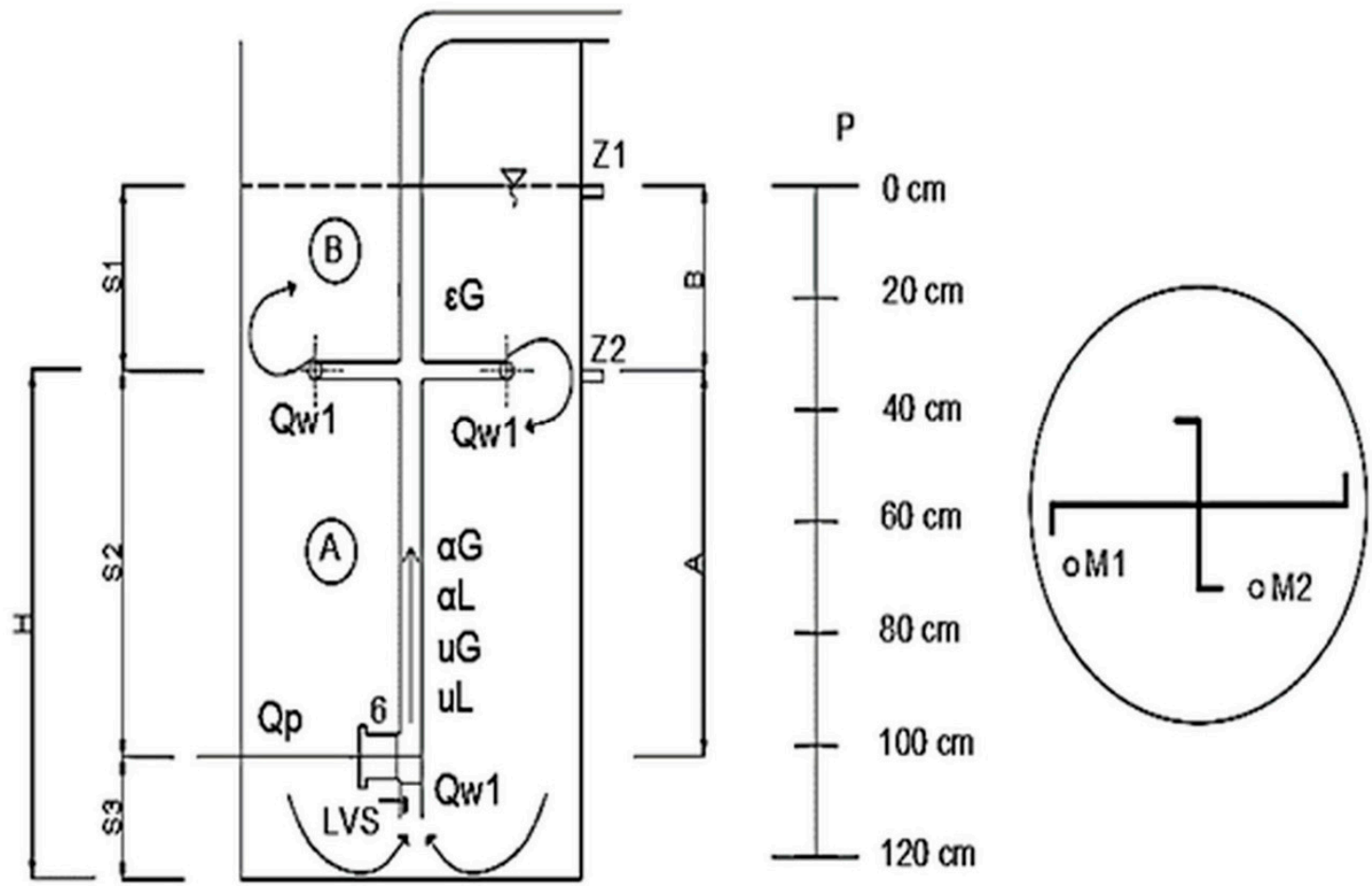

Figure 3. Diagram of hydraulic and technological tests: I-section, II-view from above, $\mathrm{P}$-measurement level of LDO, Qp — supply air flow rate, Qw1-flow rate of water in the section 6-H, LVS-liquid velocity sensor of LVS, $\alpha \mathrm{G}$-gas holdup for ALR, $\alpha \mathrm{L}$-liquid holdup for ALR, $\varepsilon \mathrm{G}$-gas holdup for BCR, uG—superficial gas velocity in the mixture, $\mathrm{uL}$-superficial liquid velocity in the mixture, S1-air bubble rising zone, S2-mixture circulation zone, S3-bottom zone, A-airlift reactor, B-bubble column reactor.

\subsection{Calculation of Mixture Parameters in the Reactor}

Parameters of a two-phase mixture in part A (ALR) at the section from the diffuser (6) to nozzle pipe element $H$ were determined applying the Zuber-Findlay flow [69]. Knowing the values of flow jets $Q_{w 1}$ and $Q_{p}$, superficial velocities $u_{G}$ and $u_{L}$ were determined for both phases: water and air. The model coefficient $C_{0}$ was calculated from the equation given by Hibiki and Ishi [71]. The flow structure was established using the flow map according to Ulbrich [74]. The drift velocity equation $\mathrm{v}_{\mathrm{dr}}$ was applied for the identified flow structure following the method proposed by Hibiki and Ishi [71]. Gas and liquid holdup of a given phase $\alpha_{\mathrm{G}}$ and $\alpha_{\mathrm{L}}$, as well as real velocity of a given phase $\mathrm{v}_{\mathrm{G}}$ and $\mathrm{v}_{\mathrm{L}}$, were determined with the use of the Zuber-Findlay model [69].

For part $\mathrm{B}(\mathrm{BCR})$, the gas holdup $\varepsilon_{\mathrm{G}}$ was established applying the volumetric method, Equation (9).

Gas flow $Q_{p}$ was controlled using a rotameter (4). The separation of air jets $Q_{p 1}$ and $Q_{p 2}$ in the hybrid reactor was determined using measured flow volume $\mathrm{Q}_{\mathrm{p} 2}$ (Figure 1).

$$
\mathrm{Q}_{\mathrm{p} 1}=\mathrm{Q}_{\mathrm{p}}-\mathrm{Q}_{\mathrm{p} 2}
$$

where $Q_{p}$ is the supply air flow rate $\left(\mathrm{m}^{3} / \mathrm{h}\right), \mathrm{Q}_{\mathrm{p} 1}$ is the flow rate of air from nozzle $H\left(\mathrm{~m}^{3} / \mathrm{h}\right)$, and $\mathrm{Q}_{\mathrm{p} 2}$ is the flow rate of the exhaust airlift pump $\left(\mathrm{m}^{3} / \mathrm{h}\right)$.

\subsection{Calculation of Aeration Parameters}

Parameters of the aeration process were calculated using the above-mentioned equations. Oxygenation capacity $O C$ was determined for all the structural design variants $\mathrm{H}$ and reactor packing $\mathrm{W}$ (Equation (1)). The calculations were performed at 3-min intervals and for all the pre-determined measurement levels $P$. Values of diffusion constants were interpolated for the measured temperature 
according to the table given by Suschka et al. [32]. Measured oxygen concentrations were used to plot the oxygen volumetric mass transfer coefficient $k_{L a}$, following the methodology presented by Suschka et al. [32]. Using Equation (2), the value of $O C_{0}$ was calculated for each design variant.

The standard oxygen transfer rate (SOTR) was calculated based on Equation (3) in relation to standard conditions (temperature $20^{\circ} \mathrm{C}$ ). Values of temperature $T$ and pressure $P_{b}$ under measurement conditions were used in Equations (3) and (4).

The standard oxygen transfer efficiency (SOTE) was calculated based on Equation (6). The mass oxygen jet from air $\mathrm{W}_{\mathrm{O} 2}$ was established from Equation (7).

The standard aeration efficiency (SAE) was determined for each variant of pipe nozzle position $\mathrm{H}$ and moving bed filling $\mathrm{W}$ (Equation (8)). The liquid volume in the aeration chamber $\mathrm{V}_{\mathrm{L}}$ for pipe nozzle position $\mathrm{H} 34$ was $0.660 \mathrm{~m}^{3}$, while that for $\mathrm{H} 84$ was $0.974 \mathrm{~m}^{3}$. The energy consumption by two blowers feeding the reactor was $2 \times 45=90 \mathrm{~W}$.

Within the framework of statistical analysis, standard deviations were calculated for the values of dissolved oxygen concentrations in the reactor. Moreover, tests were conducted to determine the significance of differences in the mean aeration parameters for various positions of the aerating pipe. The analysis of variance in simple classification was applied. The assumed significance level was $\alpha=0.05$.

\section{Results and Discussion}

\subsection{Parameters Describing Hydraulic Conditions}

Using measured flows $Q_{w 1}$ and $Q_{p}$, superficial velocities were calculated for gas $u_{G}$ and liquid $\mathrm{u}_{\mathrm{L}}$ at the pumping segment of part $\mathrm{A}$ in the reactor. Parameters of mixture $\alpha_{G}$ and $\alpha_{\mathrm{L}}$, as well as actual velocities of gas and liquid $\mathrm{v}_{\mathrm{G}}$ and $\mathrm{v}_{\mathrm{L}}$, were calculated applying the Zuber-Findlay model [69] (Figure 4).

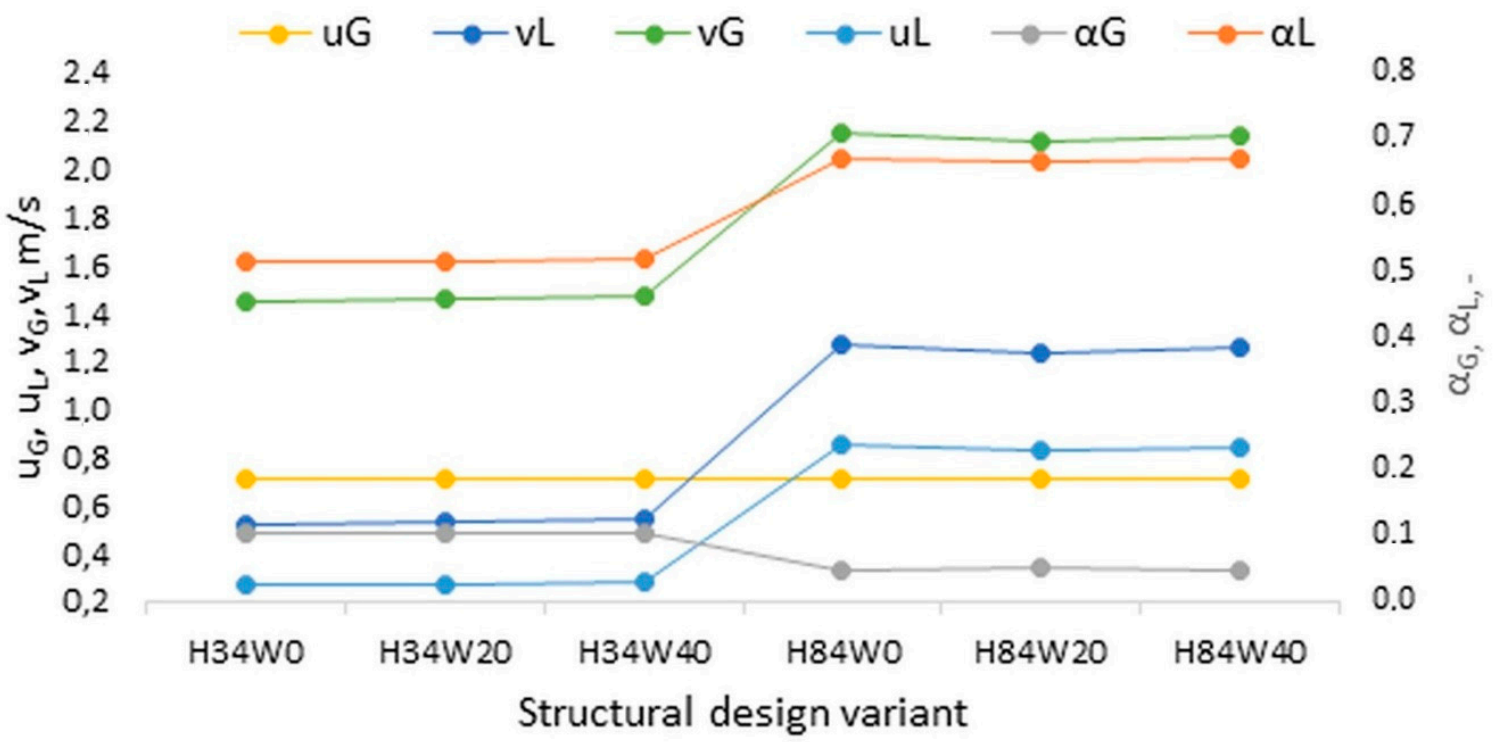

Figure 4. Superficial velocity, real velocity, and gas/liquid holdup in mixture for different variants of the reactor design: $\alpha_{\mathrm{G}}$-gas holdup for ALR, $\alpha_{\mathrm{L}}$-liquid holdup for ALR, $\mathrm{u}_{\mathrm{G}}$-superficial gas velocity in the mixture for ALR, $\mathrm{u}_{\mathrm{L}}$-superficial liquid velocity in the mixture for ALR, $\mathrm{v}_{\mathrm{L}}$-real liquid velocity in the mixture, $v_{G}$-real gas velocity in the mixture.

Superficial velocity of gas $\mathrm{u}_{\mathrm{G}}$ was constant for each structural design variant and amounted to $0.71 \mathrm{~m} / \mathrm{s}$; the calculated real velocity of gas $\mathrm{v}_{\mathrm{G}}$ for variant $\mathrm{H} 34$ was approximately $50 \%$ greater and ranged from 1.45 to 1.47 , while, for variant $\mathrm{H} 84$, it was approximately $300 \%$ greater and ranged from 
2.11 to $2.15 \mathrm{~m} / \mathrm{s}$. Superficial velocity of liquid $\mathrm{u}_{\mathrm{L}}$ also varied; for structural design variant H34, it was from 0.26 to $0.28 \mathrm{~m} / \mathrm{s}$ and, for $\mathrm{H} 84$, it was from 0.82 to $0.85 \mathrm{~m} / \mathrm{s}$. The calculated real velocity of liquid $\mathrm{v}_{\mathrm{L}}$ was almost two-fold greater; for variant $\mathrm{H} 34$, it ranged from 0.5 to $0.54 \mathrm{~m} / \mathrm{s}$, while, for variant $\mathrm{H} 84$, it was from 1.24 to $1.27 \mathrm{~m} / \mathrm{s}$. For variant $\mathrm{H} 34$, the gas holdup $\alpha_{\mathrm{G}}$, in the segment from the diffuser (6) to the nozzle pipe $\mathrm{H}$, was approximately $30 \%$ greater than for the alternative variant $\mathrm{H} 84$. This value was approximately 0.48 . The value of $\alpha_{L}$ was inversely proportional to $\alpha_{G}$ for all six structural design variants of the hybrid reactor. The location of nozzle pipe $\mathrm{H}$ at the pumping segment of the airlift (9) considerably altered proportions of the two-phase liquid-gas mixture at the segment from the diffuser (6) to the pipe element $(\mathrm{H})$ and flow velocity for both mixture phases. The higher position of the nozzle pipe $\mathrm{H}$ (H84) increased the share of liquid in the mixture and superficial velocity, as well as actual flow of liquid.

Based on the conducted laboratory analyses for part $A$ of the reactor, the value of $\alpha_{G}$ was calculated from Equation (11); for part B, the volumetric method and Equation (9) were applied. The value $\mathrm{Q}_{\mathrm{p}}=5 \mathrm{~m}^{3} / \mathrm{h}$ was constant for each structural design variant. The gas holdup $\varepsilon_{\mathrm{G}}$ for part $\mathrm{B}$ was several dozen times lower than in part A. Coefficients $\alpha_{G}$ and $\varepsilon_{G}$ were almost two-fold lower for the position of nozzle pipe $\mathrm{H} 84$ than in variant $\mathrm{H} 34$. For the position of nozzle pipe H84, the liquid holdup $\alpha_{\mathrm{L}}$ and the flow $Q_{w 1}$ took the greatest values (Figure 5).

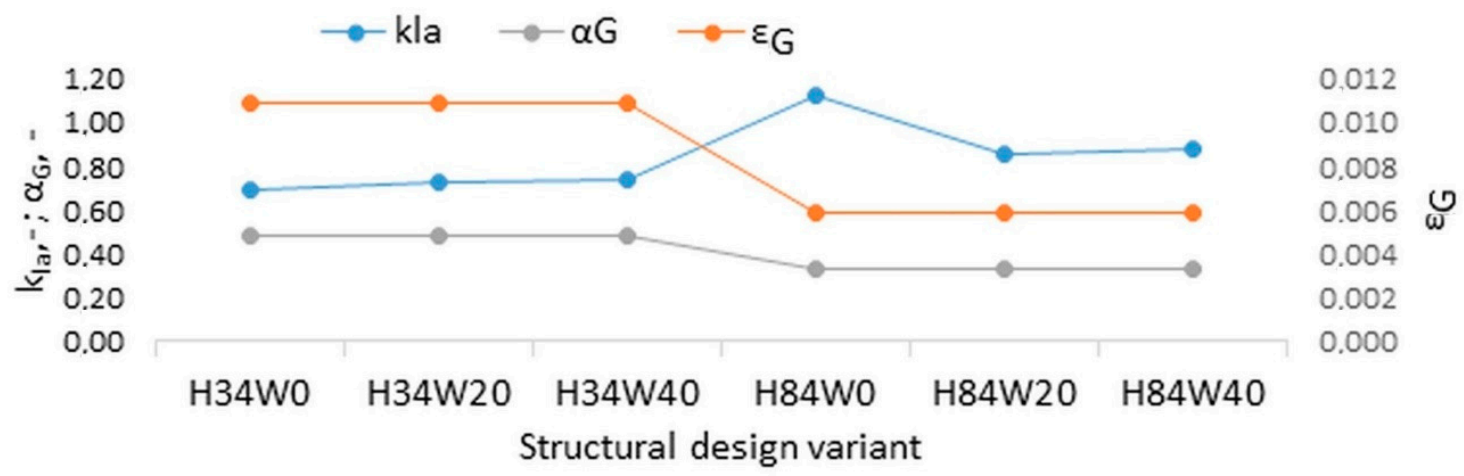

Figure 5. Gas holdup $\alpha_{\mathrm{G}}$ and $\varepsilon_{\mathrm{G}}$ and oxygen volumetric mass transfer coefficient $\mathrm{k}_{\mathrm{La}}$ for different structural design variants of the reactor.

Figures 6 and 7 present circulation velocity of the liquid vcr depending on the measurement point $\mathrm{P}$, position of nozzle pipe $\mathrm{H}$, and moving bed filling $\mathrm{W}$. The vcr for the liquid in the airlift zone S1 (Figure 3) reached maximum values thanks to the raising of large air bubbles. Circulation velocity of liquid vcr was much greater at measurement point M2. Considerable flow turbulences occurred because of the tank shape, the amount of the moving bed, and the character of flow in the liquid (Figures 6 and 7).

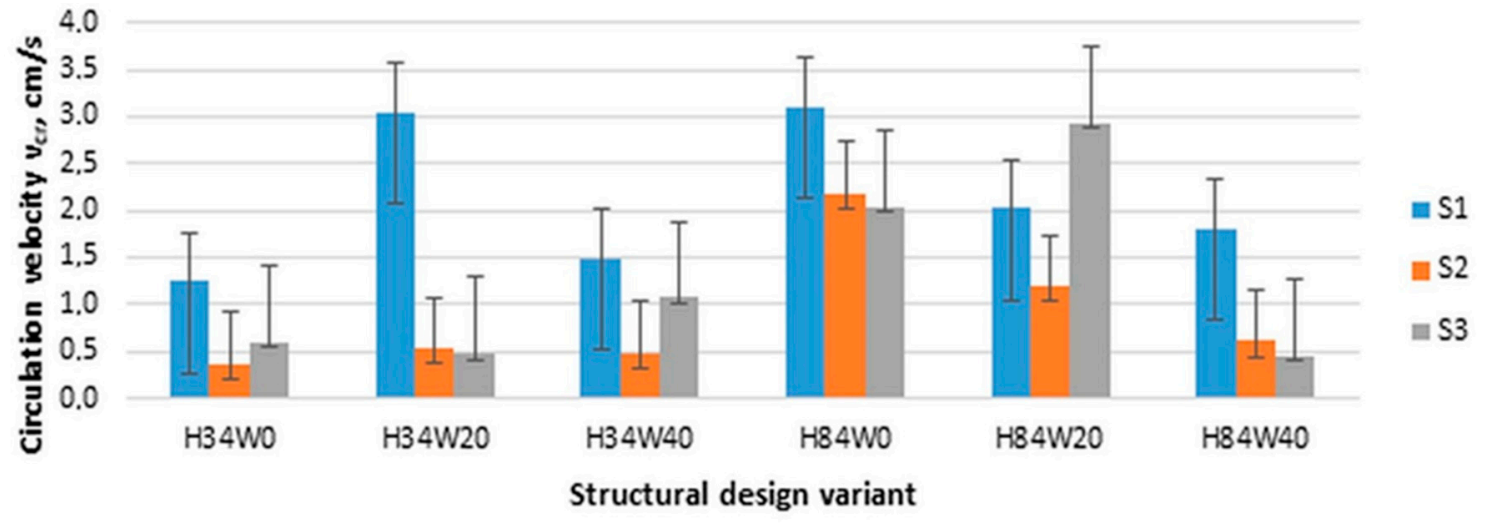

Figure 6. Circulation velocity of liquid $\mathrm{v}_{\mathrm{cr}}$ in the reactor in different measurement zones; point M1. 


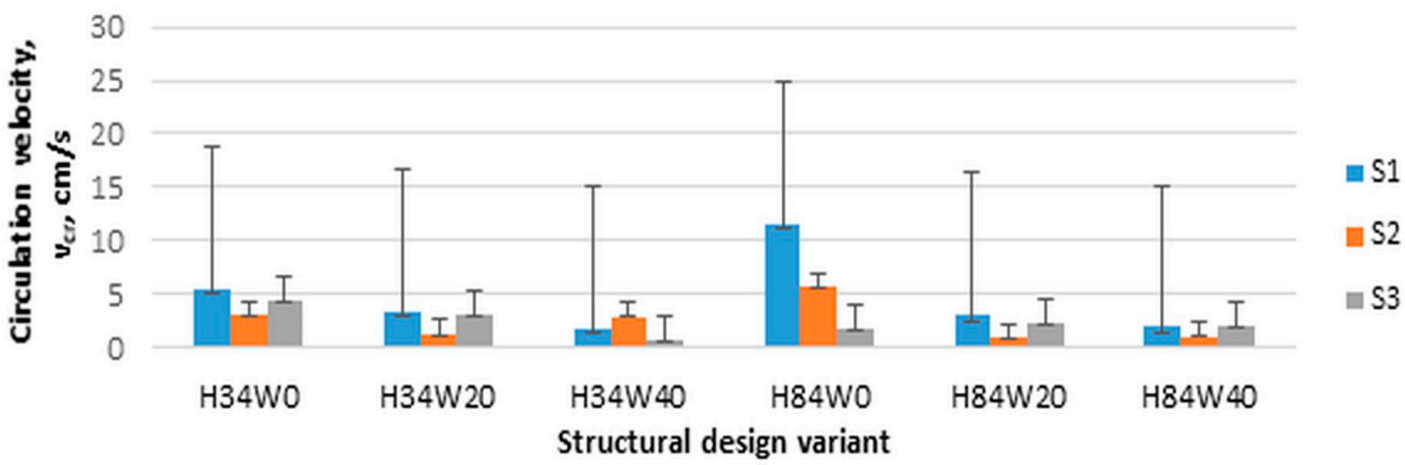

Figure 7. Circulation velocity $\mathrm{v}_{\mathrm{cr}}$ of liquid in the reactor in different measurement zones; point M2.

Figure 8 presents a graph for the mean circulation velocity of the liquid in reactor $\mathrm{v}_{\text {crs }}$. Values of $\mathrm{v}_{\text {crs }}$ for $\mathrm{H} 34$ and $\mathrm{H} 84$ decrease with moving bed filling $W$. For structural design variant H84W0, the maximum circulation velocity $\mathrm{v}_{\mathrm{crs}}$ was $4.4 \mathrm{~cm} / \mathrm{s}$ and it was almost two-fold greater compared to H34W0.

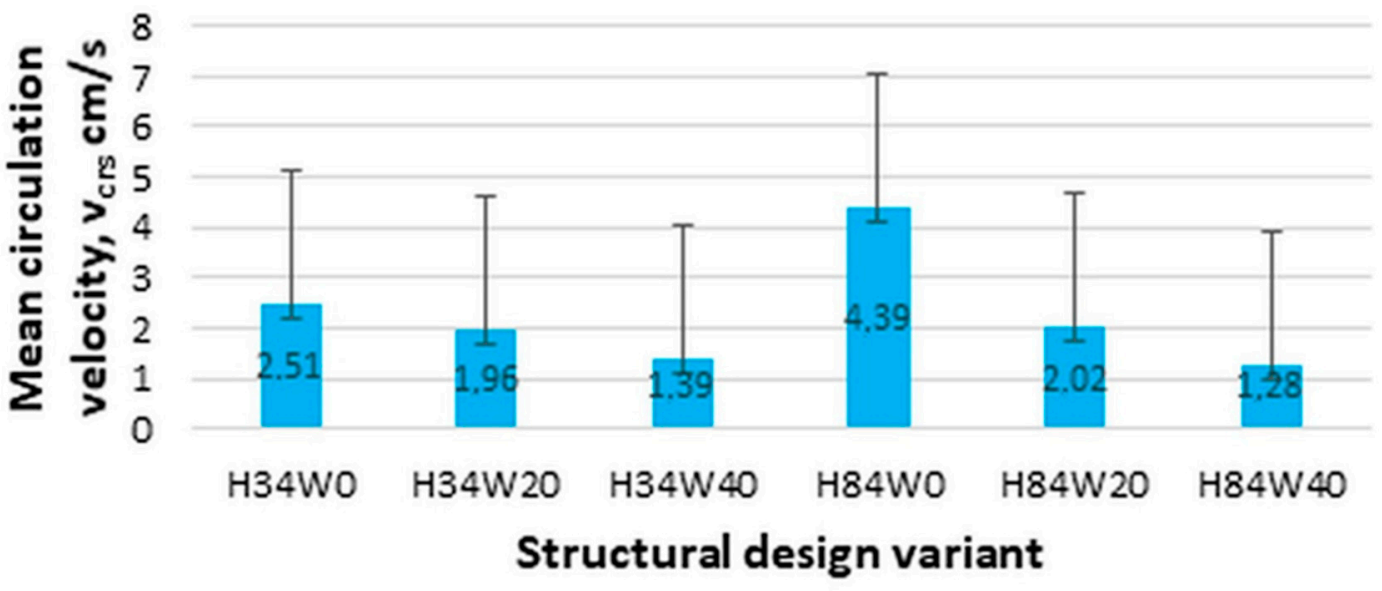

Figure 8. Mean circulation velocity $\mathrm{v}_{\mathrm{crs}}$ of liquid in the reactor.

Based on the flow regime map for bubble columns, the flow regime was identified as the churn-turbulent regime [80]. Velocity of the gas flowing from the nozzle $H$ ranged from 0.26 to $0.36 \mathrm{~m} / \mathrm{s}$. Bubbles showed very strong coalescence.

Non-dimensional parameters were calculated for all hybrid reactor designs. For the variant H34, the values were as follows: Eo $=2296-2298 ; \mathrm{Fr}=0.17-0.18 ; \log _{10} \mathrm{Mo}=-1038$ to -1039 ; $\mathrm{Re}=$ 9597-9846; $\mathrm{We}=3899-4105 ; \varepsilon_{\mathrm{g}}=109 \% ; \rho \mathrm{w}=9992-9998$. For variant $\mathrm{H} 84$, the values were as follows: $\mathrm{Eo}=2296-22,977 ; \mathrm{Fr}=0.31-0.314 ; \log _{10} \mathrm{Mo}=-10,385 ; \mathrm{Re}=13,030-13,055 ; \mathrm{We}=7186-7215$; $\varepsilon_{\mathrm{g}}=0.59 \% ; \rho \mathrm{w}=9989-9995$. These results are consistent with the literature [81]. The aspect ratio (taking into account the shape of bubbles and spherical cap) was about 0.4 and 0.3 for variants H34 and $\mathrm{H} 84$, respectively.

Using measurements of concentration of liquid dissolved oxygen (LDO) depending on time, measurement depth $(\mathrm{P})$, and structural design variant $(\mathrm{H}, \mathrm{W})$, the mean $\mathrm{LDO}$ concentrations were calculated for the entire reactor volume for 5-min intervals (Figure 9).

The analysis of measured dissolved oxygen concentrations in the reactor depending on aeration time showed that the airlift with a nozzle pipe installed at height $\mathrm{H} 84$ at the $40 \%$ reactor volume reactor filling with the moving bed provided the highest oxygen concentration in the successive time intervals. Results for the $20 \%$ moving bed filling and no reactor filling were very similar. In structural design 
variant $\mathrm{H} 34$, the best results were obtained for the $20 \%$ reactor filling with the moving bed. Values for the $40 \%$ filling and no filling in the reactor were comparable.

At various stages of the tests, $\mathrm{pH}$ values were monitored on an ongoing basis. The $\mathrm{pH}$ value of water increased during the preparation of tests from 7.2 to 8.0. The initial aeration of water removed $\mathrm{CO}_{2}$ and increased the $\mathrm{pH}$ value. The use of $\mathrm{Na}_{2} \mathrm{SO}_{3}$ caused anionic hydrolysis and an increase in $\mathrm{pH}$ from 8.0 to 8.3 .

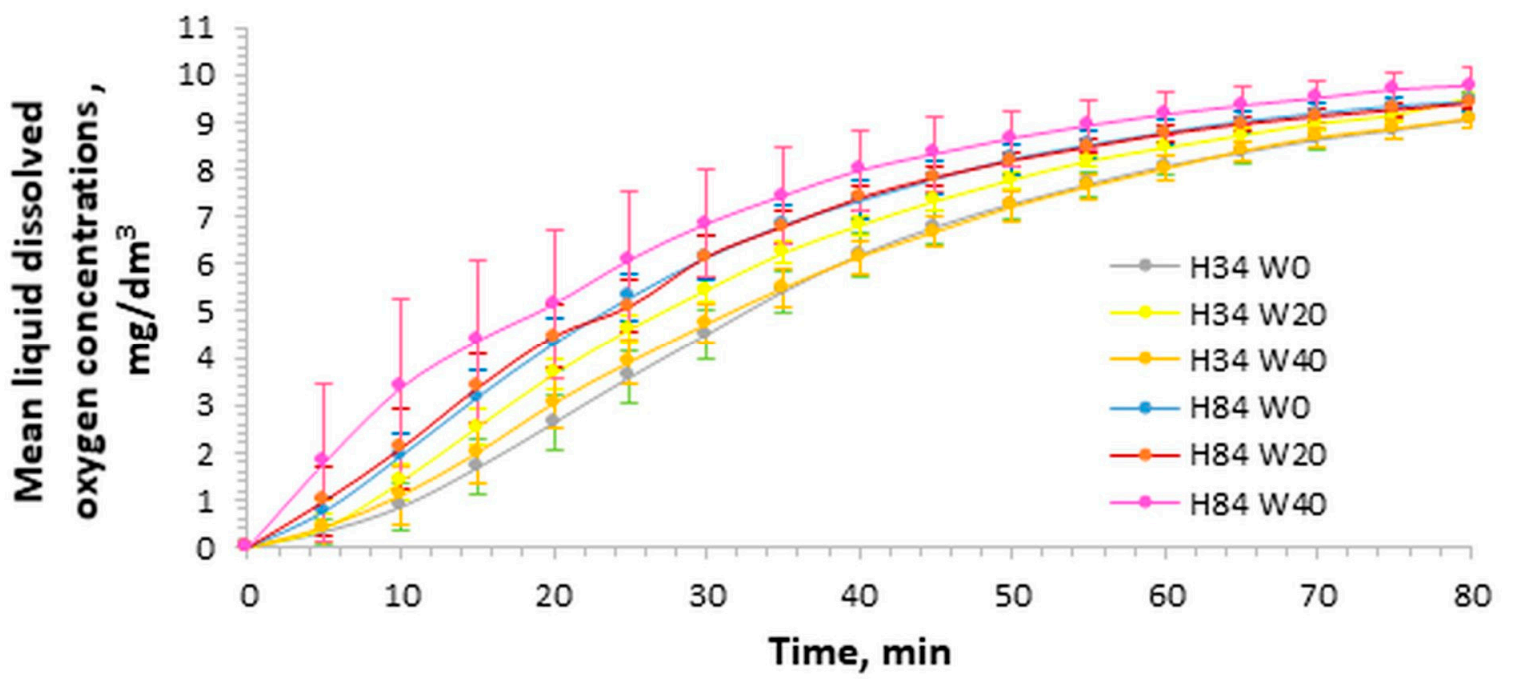

Figure 9. Mean liquid dissolved oxygen concentrations for the entire reactor volume for all structural design and filling variants.

\subsection{Parameters Describing the Aeration Process}

In order to determine aeration conditions for water in a hybrid barbotage reactor, various energy and technological parameters were determined.

The oxygen volumetric mass transfer coefficient $k_{L a}$ was established as one of the basic technological parameters describing oxygen conditions in a hybrid barbotage reactor. For this purpose, the graphic method was applied. Lines on the graph assume a shape comparable to straight lines at slope $\alpha$ to the axis of the abscissa, which confirms a correct determination of saturation concentration $c_{s}$. The tangent of slope $\alpha$ of the line to the axis of the abscissa corresponds to values of aeration rate $k_{L a}$ by Suschka et al. [32]. Values of $k_{L} a$ for H34 ranged from 0.02 to 0.97 , while those for H84 ranged from 0.06 to 1.46 (Figure 10).

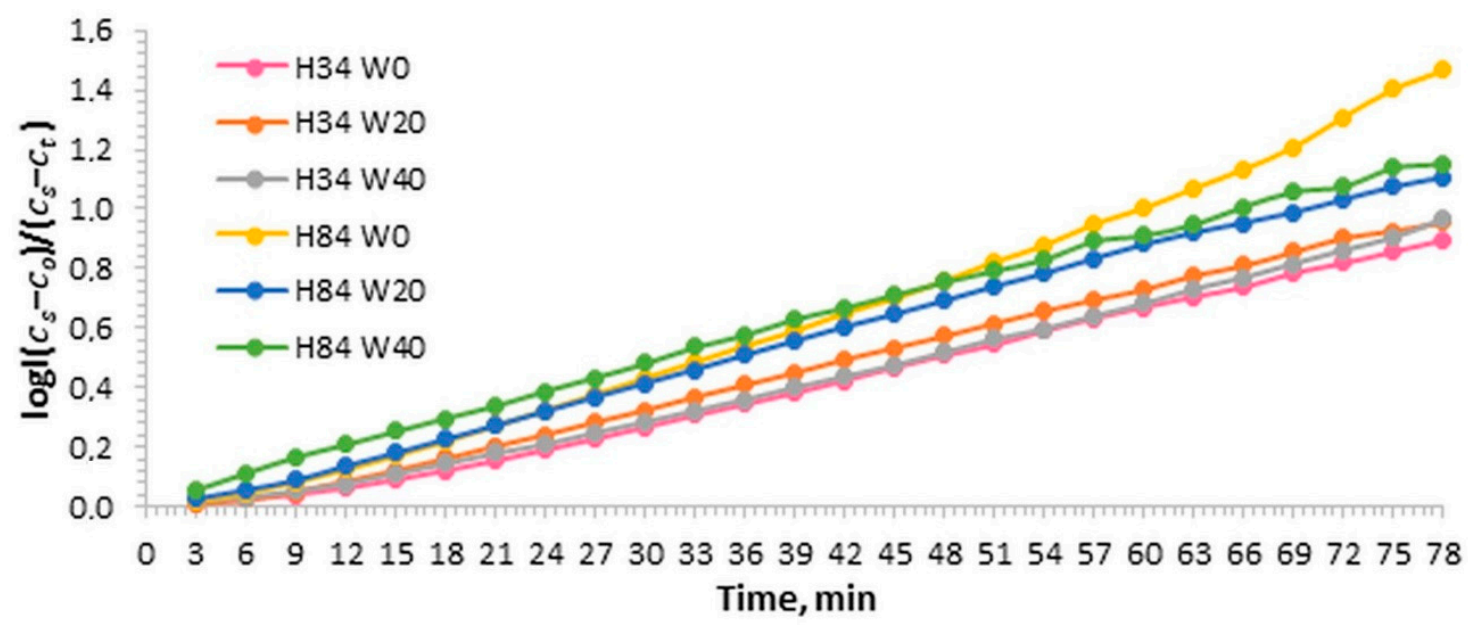

Figure 10. Determination of $k_{L} a$ using the graphic method. 
Next, the oxygenation capacity $O C$ was calculated using Equation (1). Figure 11 presents results of calculations for oxygenation capacity for a hybrid barbotage reactor depending on aeration time. Values of $O C$ were calculated at 3-min time intervals. The provided $O C$ value is a value averaged for all measurement levels $\mathrm{P}$ of the reactor, obtained at the same time point.

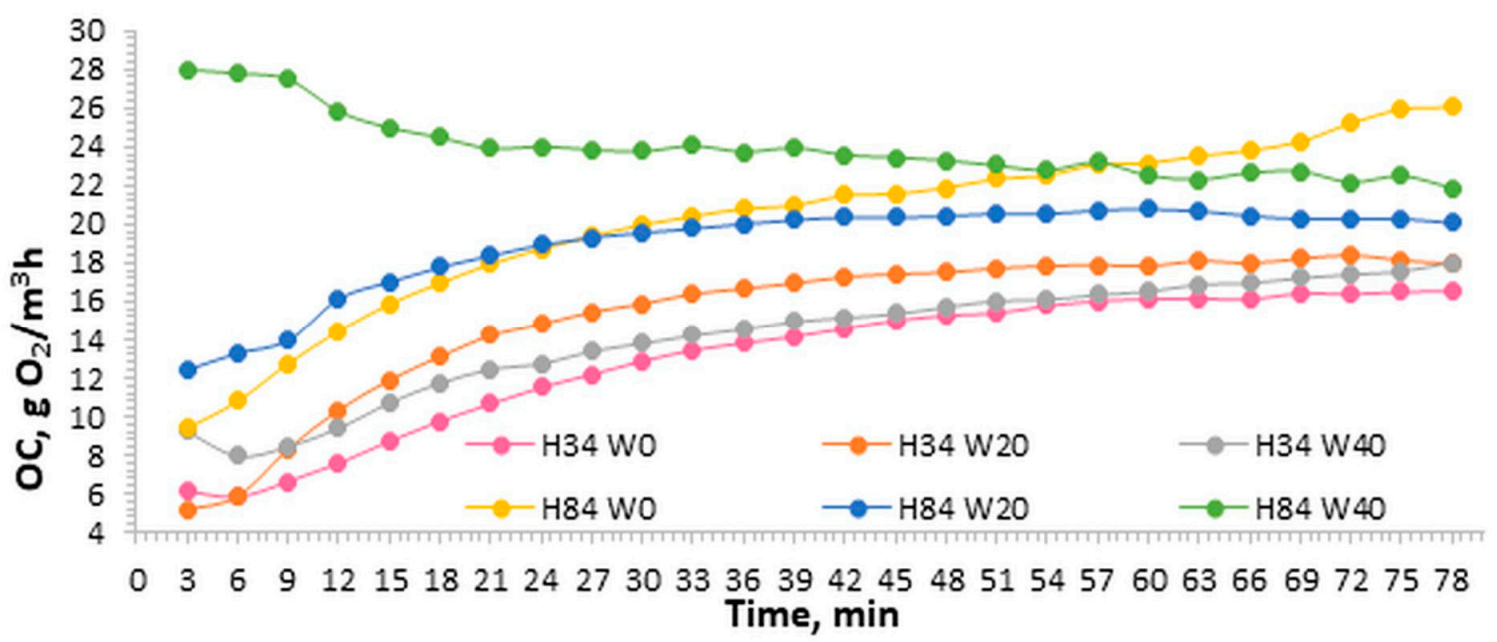

Figure 11. Oxygenation capacity of a barbotage reactor depending on aeration time for different structural design and reactor filling variants.

The values of $O C$ for all the variants except for H84W40 increased with time after the initiation of aeration, with the greatest increases observed until $21 \mathrm{~min}$. For variant H84W40, the initial value of $O C$ was greatest $\left(28 \mathrm{~g} \mathrm{O}_{2} / \mathrm{m}^{3} \cdot \mathrm{h}\right.$ ); after $21 \mathrm{~min}$, it gradually decreased to $24-22 \mathrm{~g} \mathrm{O}_{2} / \mathrm{m}^{3} \cdot \mathrm{h}$. Due to large amount of the moving bed, which hindered circulation of the liquid in the reactor $\left(\mathrm{v}_{\mathrm{crs}}=1.28 \mathrm{~cm} / \mathrm{s}\right)$, marked differences in OC were found between the P levels, as confirmed by values of standard deviation from the mean in the form of error bars. Curves for the structural design variants with nozzle pipe position $\mathrm{H} 34$, with no moving bed filling (W0) and with the $40 \%$ filling rate, took very similar shapes in measurement ranges. In turn, the mean $\mathrm{OC}$ was $1.6 \mathrm{~g} \mathrm{O}_{2} / \mathrm{m}^{3} \cdot \mathrm{h}$ greater at the same time point for H34W20 than for variants H34W0 and H34W40. Curves for all the reactor filling variants with nozzle pipe position $\mathrm{H} 84$ deviated markedly from the system for design variant $\mathrm{H} 34$. In the reactor with no moving bed filling and with the $20 \%$ filling, the values of OC up to $27 \mathrm{~min}$ of aeration were very similar, while, after that time in the reactor with no bed filing, mean OC values increased steadily, reaching a maximum of $26 \mathrm{~g} \mathrm{O}_{2} / \mathrm{m}^{3} \cdot \mathrm{h}$. In the reactor with the $20 \%$ moving bed filling rate, after $27 \mathrm{~min}$, the value of OC did not change and amounted to approximately $20 \mathrm{~g} \mathrm{O}_{2} / \mathrm{m}^{3} \cdot h$.

Table 1 presents the maximum oxygenation capacities of the hybrid barbotage reactors. Values of $O C_{0}$ for $\mathrm{H} 34$ and with different filling rates $\mathrm{W}$ were very similar. When the nozzle pipe was installed at height $\mathrm{H} 84$, the greatest value of $O C_{0}$ was recorded in the reactor with no moving bed filling, while, at the $20 \%$ and $40 \%$ filling, measured values of $O C_{0}$ were comparable. The results of calculations presented in Table 1 were close to $O C$ values obtained after 78 min under conditions close to the water saturation point with oxygen (Figure 11 and Figure S2 (Supplementary Materials)).

Table 1. Maximum oxygenation capacity of a barbotage reactor depending on nozzle pipe position $\mathrm{H}$ and moving bed filling $\mathrm{W}$.

\begin{tabular}{cccccc}
\hline \multicolumn{6}{c}{ OC $_{\mathbf{0}}$} \\
\hline \multicolumn{6}{c}{$\mathbf{g ~ O 2} / \mathbf{m}^{\mathbf{3}} \cdot \mathbf{h}$} \\
\hline H34 W0 & H34 W20 & H34 W40 & H84 W0 & H84 W20 & H84 W40 \\
\hline 16.57 & 17.67 & 17.97 & 27.93 & 20.51 & 21.88 \\
\hline
\end{tabular}


The next parameter to be calculated based on Equations (3)-(5) was the standard oxygen transfer rate $\mathrm{SOTR}_{20}$ (Figure 12). For $\mathrm{H} 34$, the $\mathrm{SOTR}_{20}$ for different reactor bed filling was comparable and amounted to approximately $5 \mathrm{~g} \mathrm{O}_{2} / \mathrm{h}$. For H84, SOTR 20 in the reactor with no moving bed filling (W0) was on average $22 \%$ greater than filling variants $\mathrm{W} 20$ and $\mathrm{W} 40$. The mean value of SOTR 20 for variant H84 was almost 50\% greater than the results for variant $\mathrm{H} 34$.

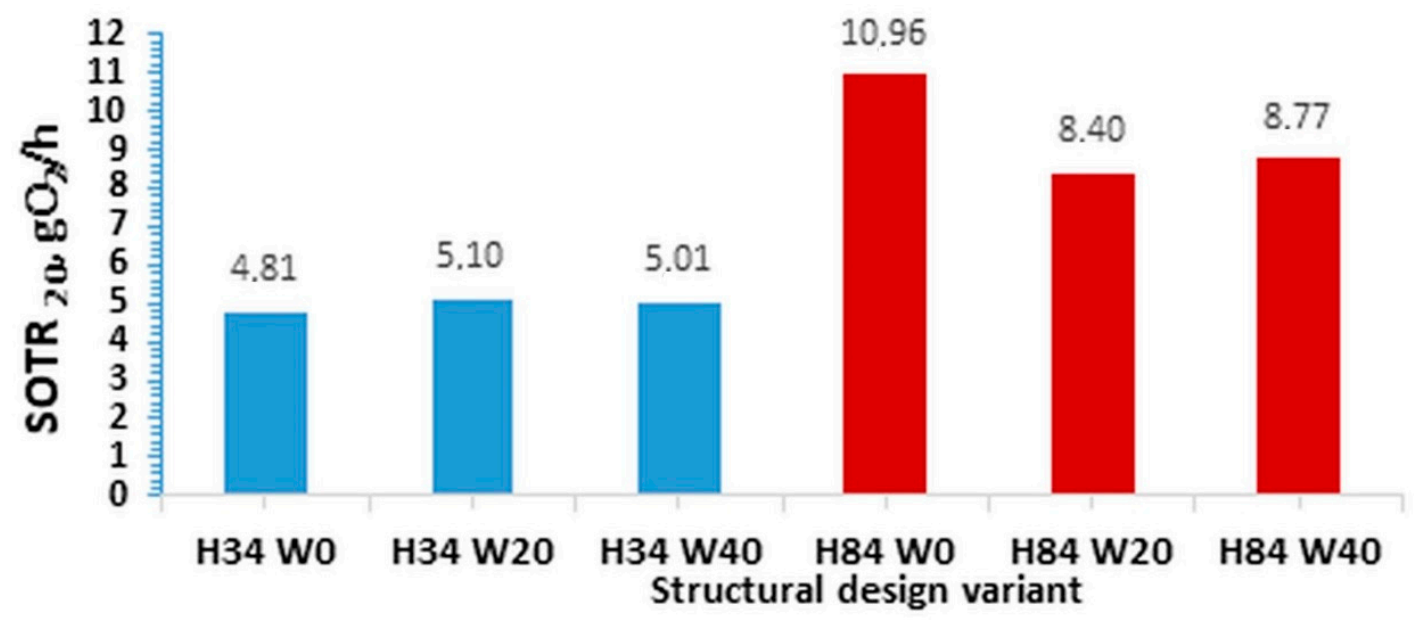

Figure 12. Standard oxygen transfer rate $\left(\mathrm{SOTR}_{20}\right)$ in the tested barbotage reactor.

Based on Equations (6) and (7), the standard oxygen transfer efficiency (SOTE) was calculated under standard conditions (Figure 13). Values of SOTE for the six tested structural design variants were comparable, with the highest SOTE of $8.48 \%$ obtained for the reactor with nozzle pipe position H84 with no moving bed filling. In contrast, the lowest oxygen transfer efficiency was found for the reactor with nozzle pipe position $\mathrm{H} 34$ and no bed filling. The air jet flow $\mathrm{Q}_{\mathrm{p} 1}$ was determined in hydraulic tests applying the volumetric method (Figure 1). Using measured values of air flow $Q_{p 1}$ supplied by the aerator (in this case, the nozzle for mixture circulation and aeration), the oxygen mass jet flow $\mathrm{W}_{\mathrm{O} 2}$ was calculated. Despite considerable difference in jet volume, differences between SOTE for design variants $\mathrm{H} 34$ and $\mathrm{H} 84 \mathrm{~cm}$ were small. This was the result of nozzle depth $\mathrm{H}_{\mathrm{d}}$, greater than $10 \mathrm{~cm}$, thanks to which the contact time of the air-water mixture with structure H34 increased by approximately $20 \%$.

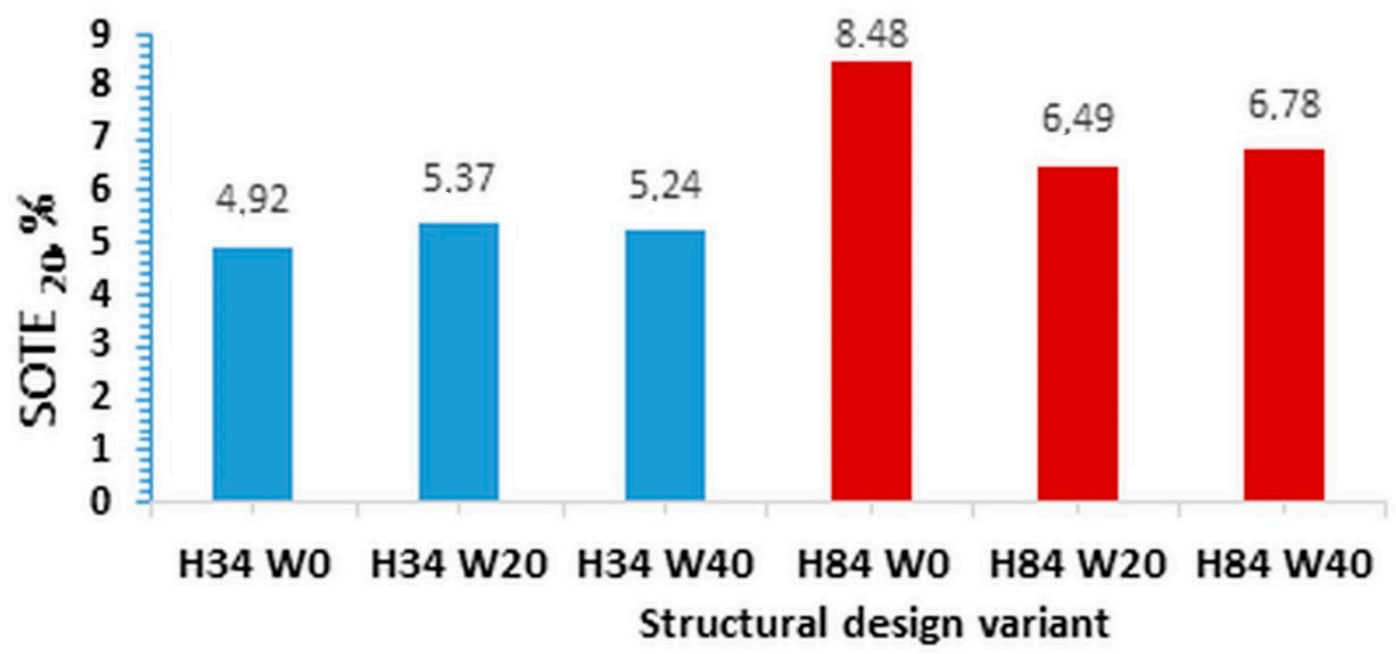

Figure 13. Standard oxygen transfer efficiency (SOTE) in the tested barbotage reactor. 
Standard aeration efficiency (SAE) was determined for each variant of nozzle position $H$ and moving bed filling $W$ (Equation (8)). The consumption of electric energy by the two blowers supplying the reactor was $2 \times 45=90 \mathrm{~W}$. Values of energy efficiency for individual variants of a hybrid barbotage reactor were analogous to those of the standard oxygen transfer efficiency (Figure 14).

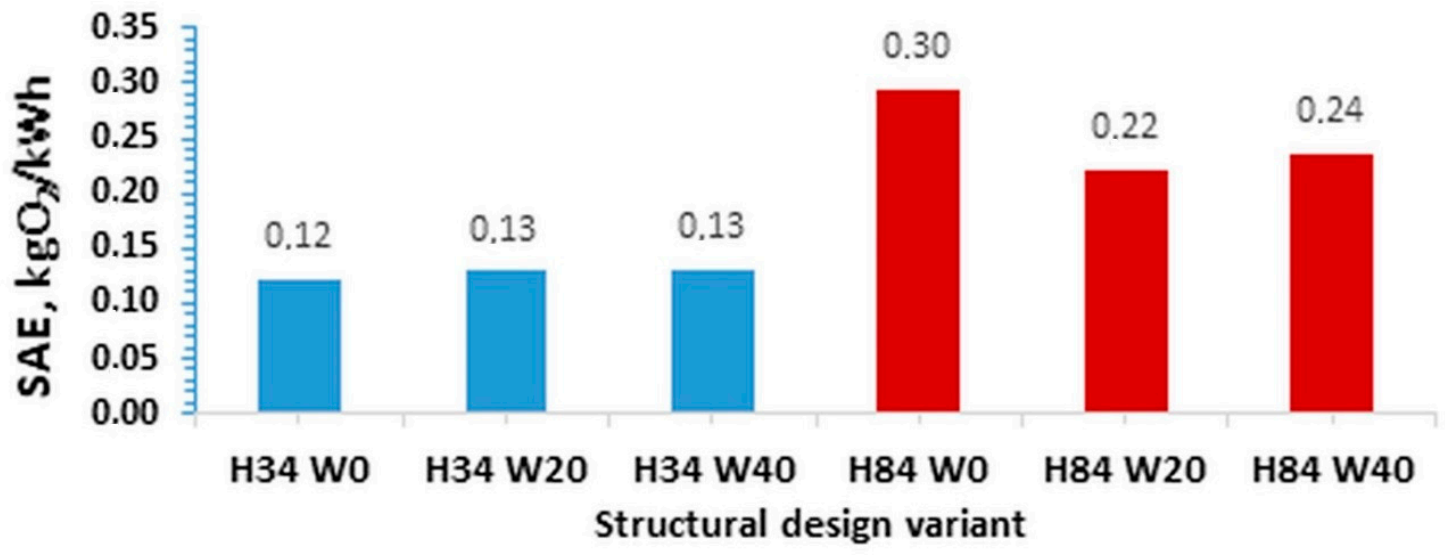

Figure 14. Standard aeration efficiency (SAE) in the tested barbotage reactor.

\subsection{Statistical Analysis of Research Results}

Statistical analysis of the results was conducted in order to confirm the significance of observed differences between individually tested design variants of the hybrid reactor and the reactor filling rate with the moving bed. The analysis of variance in simple classification was applied to confirm the effect of nozzle position $\mathrm{H}$ and moving bed filling $\mathrm{W}$ on aeration conditions by testing the significance of differences in the means (Table 2). In the statistical analysis of the results, the significance level was adopted at $\alpha=0.05$.

Table 2. Analysis of variance for means: a comparison of the effect of reactor structural design on oxygenation capacity OC. "Yes"—statistically significant effect; "No"—statistically non-significant effect; MS—mean square; df-degrees of freedom.

\begin{tabular}{|c|c|c|c|c|c|c|}
\hline \multicolumn{7}{|c|}{$\begin{array}{c}\text { Tukey's HSD Test; } \alpha=0.05 \\
\text { Approximated Probabilities for Post Hoc Tests } \\
\text { Error: Intergroup MS }=16.965, \mathrm{df}=84.000\end{array}$} \\
\hline Structural Design Variant & $\begin{array}{l}\text { H34 } \\
\text { W0 }\end{array}$ & $\begin{array}{l}\text { H34 } \\
\text { W20 }\end{array}$ & $\begin{array}{l}\text { H34 } \\
\text { W40 }\end{array}$ & $\begin{array}{l}\text { H84 } \\
\text { W0 }\end{array}$ & $\begin{array}{l}\text { H84 } \\
\text { W20 }\end{array}$ & $\begin{array}{l}\text { H84 } \\
\text { W40 }\end{array}$ \\
\hline H34 W0 & & No & No & Yes & Yes & Yes \\
\hline H34 W20 & No & & No & Yes & Yes & Yes \\
\hline H34 W40 & No & No & & Yes & Yes & Yes \\
\hline H84 W0 & Yes & Yes & Yes & & No & Yes \\
\hline H84 W20 & Yes & Yes & Yes & No & & Yes \\
\hline H84 W40 & Yes & Yes & Yes & Yes & Yes & \\
\hline
\end{tabular}

Based on the results from the analysis of variance, the height of the aerating nozzle $\mathrm{H}$ above the reactor bottom at an identical moving bed filling rate $W$ had a significant effect on oxygenation capacity OC (Table 2). For the nozzle located at H34 and for all the analyzed moving bed filling variants W, the OC values did not differ significantly; for the nozzle pipe at height H84, there were no differences between the reactor filling with the moving bed $\mathrm{W}=0 \%$ and $20 \%$. 


\subsection{Concluding Remarks}

Based on the conducted hydraulic tests and aeration in a hybrid barbotage reactor, the effect of nozzle position $\mathrm{H}$ and bed filling variant $\mathrm{W}$ on aeration efficiency in the reactor was investigated. It was found that the structural design variant of the reactor with an airlift and with a nozzle installed at height $\mathrm{H} 84$ and the moving bed filling $40 \%$ reactor volume provided the greatest oxygen concentration during aeration compared to other filling variants $(0 \%$ and $20 \%)$. Values of oxygen concentrations in the reactor for this design variant at different measurement depths $P$ varied greatly. A large volume of the moving bed considerably reduced circulation of the liquid in the reactor, with the mean circulation velocity of the mixture being the smallest among all the structural design variants of the hybrid reactor $\left(\mathrm{v}_{\mathrm{crs}}=1.28 \mathrm{~cm} / \mathrm{s}\right)$. Values of oxygen concentrations in the reactor for the $20 \%$ moving bed filling and without it were very similar. In structural design variant $\mathrm{H} 34$, the most advantageous oxygen concentrations were obtained for the $20 \%$ reactor filling with the moving bed due to bed circulation in the reactor. Values of oxygen concentration for the $40 \%$ filling and absence of filling were similar; the reduction of bed circulation for the $40 \%$ filling rate and a shorter air and water contact time at the absence of the bed (W0) resulted in a deterioration of oxygen conditions.

This is confirmed by the results of Reference [56]. The liquid flow rate at point M1 of the hybrid reactor was much lower than the speed at point M2. This was due to a different length of the nozzle and proximity to the tank wall, which was confirmed by References $[55,56,82]$.

Values of maximum oxygenation capacity $O C_{0}$ for the structural design variant with the aeration nozzle installed at height $\mathrm{H} 34$ were very similar, irrespective of the filling rate with the moving bed $\mathrm{W}$. The highest $O C_{0}$ value $\left(27.9 \mathrm{~g} \mathrm{O}_{2} / \mathrm{m}^{3} \cdot \mathrm{h}\right)$ was obtained in the structural design variant with no moving bed filling, when the nozzle was installed at height $\mathrm{H} 84$. For the $20 \%$ and $40 \%$ filling rates with the moving bed, $O C_{0}$ values were similar.

Values of SOTR and SOTE for the structural design variant of the reactor with the nozzle installed at height $\mathrm{H} 34$ were very similar irrespective of the moving bed filling rate $W$. The greatest values of SOTE and SOTR were found for the design variant H84. In comparison to the most frequent aeration systems using compressed air most commonly found in practice (immersion, using fine-bubble column diffusors), values of SOTR and SOTE for the H84W0 design variant were two-fold lower (NOPON PIK300). The SAE of $0.3 \mathrm{~kg} \mathrm{O}_{2} / \mathrm{kWh}$ for the $\mathrm{H} 84 \mathrm{W0}$ variant was three times lower than that found in literature; for example, Collivignarelli et al. [5] gave an SAE of approximately $1.09-1.59 \mathrm{~kg} \mathrm{O}_{2} / \mathrm{kWh}$, while others gave an SAE of $2.5 \mathrm{~kg} \mathrm{O}_{2} / \mathrm{kWh}$ [83]. Values reported in this study resulted from a small interphase surface in the mixture in relation to a considerable reactor volume and a limited immersion of the nozzle used for circulation and aeration (under standard conditions, aerators are tested at a depth of $4 \mathrm{~m}$ ). Additionally, considerable flow losses (approximately $30 \%$ ) were observed in the installation supplying air to the nozzle, which were caused by the rotameter. The results of the conducted experiments were very similar to those reported by Loyless and Malone [10], who stated that the parameter values describing the aeration process for airlift were much lower than for aeration in the fine-bubble column using compressed air. The value of $k_{L a}$ increases with gas velocity, while it decreases with an increase in the concentration of the solids (moving bed) and with liquid viscosity [84-86].

The previously mentioned scaling effect was indicated in studies by, e.g., Benyahia and Jones [62]. During the experiments, in which they studied gas retention and oxygen transfer, they noticed significant differences depending on the scale of the reactor. Two geometrically similar systems were tested, with the difference that, in the large one, the liquid height in the gas-liquid separator was $20 \mathrm{~cm}$, while, in the small variant, it was $10 \mathrm{~cm}$, meaning that the total liquid volume $\left(\mathrm{dm}^{3}\right)$ was about 108 and 13.5, respectively. Based on mass transfer studies, two important aspects were noted. Firstly, the sampling position is important because significantly different $k_{L a}$ values may be obtained. Changes in $k_{L} a$ with the location of the probe were explained in terms of heterogeneous hydrodynamic properties, with the results obtained being confirmed by recordings from a high-speed video camera. The other aspect showed that, at higher gas flows, gas retention was much higher in the large-scale reactor. In 
order to keep the gas retention or $k_{L a}$ constant in both reactors, the small-scale reactor required $25 \%$ to $27 \%$ more power per unit volume of liquid.

While analyzing the effect of the structural design variant on aeration, it was observed that nozzle position $\mathrm{H}$ affects aeration efficiency to a greater extent than moving bed filling rate $\mathrm{W}$. For the H84 structural design variant with no moving bed, the circulation velocity of liquid $\mathrm{v}_{\mathrm{crs}}$ in the reactor was greatest. The reactor filling rate using moving bed $\mathrm{W}$ may considerably reduce the circulation of the mixture and affect mixing of the water-air mixture in the reactor.

When analyzing parameters of the two-phase mixture for parts $\mathrm{A}$ and $\mathrm{B}$ of the hybrid barbotage reactor, the most intensive aeration of the liquid was observed in part $A$ of the reactor. This was confirmed by gas holdup $\alpha_{G}$ (part A), which was greater than $\varepsilon_{G}$ (part B). Additionally, the flow distance for the mixture from the diffuser (6) to nozzle $\mathrm{H}$ was longer; in variant $\mathrm{H} 34$, it was $12 \mathrm{~cm}$, while, for $\mathrm{H} 84$, it was as much as $62 \mathrm{~cm}$, while the oxygen retention time in the mixture increased.

The identified air bubble flow structure for BCR was a turbulent flow, for which the mass transfer rate $k_{L} a$ is markedly lower than for homogeneous flows [37,39-41]. The use of a moving bed reduced the liquid-gas interphase surface. Additionally, it caused coalescence of air bubbles and the formation of a preferential flow path for the mixture in the moving bed, i.e., the channeling effect. Vandu and Krishna [87] observed that an addition of solid particles at a high concentration caused a decrease in $k_{L} a / \varepsilon_{G}$ values due to the increased bubble size.

For ALR, the mass transfer rate $k_{L} a$ increased with velocity of gas $\mathrm{v}_{\mathrm{G},}$, which is consistent with literature data [58,59].

It was found that, in terms of aeration effects, the most advantageous variant was structural design variant $\mathrm{H} 84$ in all analyzed filling variants with the moving bed. A greater volume of the bed increased the air and liquid contact time on the condition that it facilitated circulation in the reactor.

The use of a moving bed reduced the mean circulation velocity of the mixture in the reactor $\mathrm{v}_{\text {crs }}$. Among the six analyzed structural design variants, the moving bed filling rate had no significant effect on oxygenation capacity; for one structural design variant, the absence of bed filling considerably improved oxygen conditions by as much as approximately $41 \%$.

\section{Conclusions}

Based on the conducted hydraulic tests and aeration in a hybrid barbotage reactor, that the following results were found:

- A specially designed additional nozzle $\mathrm{H}$, installed at the pumping segment of the airlift behind diffuser (6), influences circulation and mixing of the water-air mixture in the reactor;

- Due to the variation in the two-phase structure in the pumping segment of the airlift and decompression of air bubbles, in structural design variant $H 84$, flows $Q_{w 1}$ and $Q_{p 1}$ were much greater than for the H34 design variant;

- The analysis of aeration in a hybrid reactor showed that, in each of the six structural design variants, part A (airlift reactor) affected aeration efficiency to a greater extent than part B (bubble column reactor), which was mostly influenced by the internal circulation in part A;

- The use of a moving bed may improve aeration efficiency in the reactor, provided that conditions for free circulation inside the reactor are maintained.

Supplementary Materials: The following are available online at http://www.mdpi.com/2073-4441/12/3/724/s1: Figure S1: Block diagram of hydraulic and technological tests (aeration); Figure S2: Oxygenation capacity of a barbotage reactor depending on aeration time for different structural design and reactor filling variants (along with error bars).

Author Contributions: Conceptualization, S.K. and M.M.; data curation, S.K., M.M., and J.M.; formal analysis, S.K.; funding acquisition, M.M.; investigation, S.K. and M.M.; methodology, S.K. and M.M.; resources, S.K., M.M., and J.M.; software, S.K.; supervision, M.M.; validation, S.K. and M.M.; visualization, S.K. and J.M.; writing-original draft, S.K. and J.M.; writing-review and editing, S.K. and J.M. All authors have read and agreed to the published version of the manuscript. 
Funding: This research received no external funding.

Acknowledgments: The publication was co-financed/financed within the framework of the Ministry of Science and Higher Education program as "Regional Initiative Excellence” in years 2019-2022, Project No. 005/RID/2018/19).

Conflicts of Interest: The authors declare no conflicts of interest. The funders had no role in the design of the study; in the collection, analyses, or interpretation of data; in the writing of the manuscript, or in the decision to publish the results.

\section{References}

1. Zheng, Z.; Chen, Y.; Zhan, X.; Gao, M.; Wang, Z. Mass transfer intensification in a novel airlift reactor assembly with helical sieve plates. Chem. Eng. J. 2018, 342, 61-70. [CrossRef]

2. Ziegenhein, T.; Lucas, D.; Besagni, G.; Inzoli, F. The Bubble Shape in Contaminated Bubbly Flows: Results for Different $\mathrm{NaCl}$ Concentrations in Purified Water. ChemEngineering 2018, 2, 18. [CrossRef]

3. Li, D.; Guo, K.; Li, J.; Huang, Y.; Zhou, J.; Liu, H.; Liu, C. Hydrodynamics and bubble behaviour in a three-phase two-stage internal loop airlift reactor. Chin. J. Chem. Eng. 2018, 26, 1359-1369. [CrossRef]

4. Karimi, A.; Golbabaei, F.; Mehrnia, M.R.; Neghab, M.; Mohammad, K.; Nikpey, A.; Pourmand, M.R. Oxygen mass transfer in a stirred tank bioreactor using different impeller configurations for environmental purposes. Iran. J. Environ. Health Sci. Eng. 2013, 10, 6. [CrossRef]

5. Collivignarelli, M.C.; Abbà, A.; Bertanza, G. Oxygen transfer improvement in MBBR process. Environ. Sci. Pollut. Res. 2019, 26, 10727-10737. [CrossRef]

6. Chmielowski, K.; Mazur, R.; Nowak, A.; Bedla, D.; Mazurkiewicz, J.; Spychała, M. Efficiency of Nutrient Removal from Household Wastewater in Nonwoven Bioreactors. Pol. J. Environ. Stud. 2019, 28, 2099-2108. [CrossRef]

7. Chmielowski, K.; Dacewicz, E.; Bedla, D.; Mazur, R. The Use of Plastic Waste in Biofilters for Domestic Sewage Treatment. Przem. Chem. 2018, 1, 46-49. [CrossRef]

8. Mazur, R.; Chmielowski, K.; Bedla, D.; Nowak, A.; Mazurkiewicz, J. The effect of oxygen condition on effectiveness of sewage treatment in submersible technology of nonwoven filters. Przem. Chem. 2016, 1 , 91-95. [CrossRef]

9. Yao, D.; Lee, K.; Ha, M.; Cheong, C.; Lee, I. Development of Hybrid Airlift-Jet Pump with Its Performance Analysis. Appl. Sci. 2018, 8, 1413. [CrossRef]

10. Loyless, J.C.; Malone, R.F. Evaluation of air-lift pump capabilities for water delivery, aeration, and degasification for application to recirculating aquaculture systems. Aquac. Eng. 1998, 18, 117-133. [CrossRef]

11. Ziegenhein, T.; Zalucky, J.; Rzehak, R.; Lucas, D. On the hydrodynamics of airlift reactors, Part I: Experiments. Chem. Eng. Sci. 2016, 150, 54-65. [CrossRef]

12. Ziegenhein, T.; Lucas, D. Observations on bubble shapes in bubble columns under different flow conditions. Exp. Therm. Fluid Sci. 2017, 85, 248-256. [CrossRef]

13. Deng, Z.; Wang, T.; Zhang, N.; Wang, Z. Gas holdup, bubble behavior and mass transfer in a $5 \mathrm{~m}$ high internal-loop airlift reactor with non-Newtonian fluid. Chem. Eng. J. 2010, 160, 729-737. [CrossRef]

14. Shaikh, A.; Al-Dahhan, M. Scale-up of Bubble Column Reactors: A Review of Current State-of-the-Art. Ind. Eng. Chem. Res. 2013, 52, 8091-8108. [CrossRef]

15. Luo, K.H.; Xia, J.; Monaco, E. Multiscale modeling of multiphase flow with complex interactions. J. Multiscale Model. 2009, 1, 125-156. [CrossRef]

16. Wagner, C.; Shishkin, A.; Shishkina, O. The use of Direct Numerical Simulations for solving industrial flow problems. In Proceedings of the Direct and Large-Eddy Simulation VIII; Kuerten, H., Geurts, B., Armenio, V., Fröhlich, J., Eds.; Springer: Dordrecht, The Netherlands, 2011; pp. 397-404. [CrossRef]

17. Joshi, J.B.; Nandakumar, K.; Evans, G.M.; Pareek, V.K.; Gumulya, M.M.; Sathe, M.J.; Khanwale, M.A. Bubble generated turbulence and direct numerical simulations. Chem. Eng. Sci. 2017, 157, 26-75. [CrossRef]

18. Pope, S.B. Turbulent Flows by Stephen B. Pope. Available online: https://www.cambridge.org/core/books/tur bulent-flows/C58EFF59AF9B81AE6CFAC9ED16486B3A (accessed on 11 October 2019).

19. Medjiade, W.T.; Alvaro, A.R.; Schumpe, A. Flow regime transitions in a bubble column. Chem. Eng. Sci. 2017, 170, 263-269. [CrossRef] 
20. Andersson, M.; Yuan, J.; Sundén, B. Review on modeling development for multiscale chemical reactions coupled transport phenomena in solid oxide fuel cells. Appl. Energy 2010, 87, 1461-1476. [CrossRef]

21. Grew, K.N.; Chiu, W.K.S. A review of modeling and simulation techniques across the length scales for the solid oxide fuel cell. J. Power Sources 2012, 199, 1-13. [CrossRef]

22. Jaworski, Z.; Zakrzewska, B. Towards multiscale modelling in product engineering. Comput. Chem. Eng. 2011, 35, 434-445. [CrossRef]

23. The Role of Computational Fluid Dynamics in Process Industries. Available online: https://nae.edu/7564/The RoleofComputationalFluidDynamicsinProcessIndustries (accessed on 11 October 2019).

24. Stefan, K.; Gunther, R. CFD-Simulations in the Early Product Development. Procedia CIRP 2016, 40, 443-448. [CrossRef]

25. Pöpel, H.J. Aeration and Gas Transfer. Available online: https://www.ircwash.org/resources/aeration-and-g as-transfer. (accessed on 11 October 2019).

26. Dang, N.D.P.; Karrer, D.A.; Dunn, I.J. Oxygen transfer coefficients by dynamic model moment analysis. Biotechnol. Bioeng. 1977, 19, 853-865. [CrossRef]

27. Linek, V.; Benes, P.; Vacek, V. Dynamic pressure method for kla measurement in large-scale bioreactors. Biotechnol. Bioeng. 1989, 33, 1406-1412. [CrossRef] [PubMed]

28. Linek, V.; Moucha, T.; Doušová, M.; Sinkule, J. Measurement of kLa by dynamic pressure method in pilot-plant fermentor. Biotechnol. Bioeng. 1994, 43, 477-482. [CrossRef] [PubMed]

29. Bandyopadhyay, B.; Humphrey, A.E.; Taguchi, H.; Rao, G. Dynamic measurement of the volumetric oxygen transfer coefficient in fermentation systems. Biotechnol. Bioeng. 2009, 104, 841-853. [CrossRef]

30. He, Z.; Petiraksakul, A.; Meesapya, W. Oxygen-Transfer Measurement in Clean Water-PDF. Available online: https://docplayer.net/23826942-Oxygen-transfer-measurement-in-clean-water.html (accessed on 30 October 2019).

31. Capela, S.; Gillot, S.; Héduit, A. Comparison of Oxygen-Transfer Measurement Methods under Process Conditions. Water Environ. Res. 2004, 76, 183-188. [CrossRef]

32. Kujawiak, S.; Makowska, M.; Matz, R.; Gawrońska, A. The Efficiency of the Aeration Process in Airlift Reactors with Moving Beds. Tech. Trans. 2017, 2017, 167-172. [CrossRef]

33. Prakash, A.; Margaritis, A.; Li, H.; Bergougnou, M.A. Hydrodynamics and local heat transfer measurements in a bubble column with suspension of yeast. Biochem. Eng. J. 2001, 9, 155-163. [CrossRef]

34. Gholamzadehdevin, M.; Pakzad, L. Hydrodynamic characteristics of an activated sludge bubble column through computational fluid dynamics (CFD) and response surface methodology (RSM). Can. J. Chem. Eng. 2019, 97, 967-982. [CrossRef]

35. Paździor, K.; Wrębiak, J.; Klepacz-Smółka, A.; Gmurek, M.; Bilińska, L.; Kos, L.; Sójka-Ledakowicz, J.; Ledakowicz, S. Influence of ozonation and biodegradation on toxicity of industrial textile wastewater. J. Environ. Manag. 2017, 195, 166-173. [CrossRef]

36. Kantarci, N.; Borak, F.; Ulgen, K.O. Bubble column reactors. Process Biochem. 2005, 40, 2263-2283. [CrossRef]

37. Shu, S.; Vidal, D.; Bertrand, F.; Chaouki, J. Multiscale multiphase phenomena in bubble column reactors: A review. Renew. Energy 2019, 141, 613-631. [CrossRef]

38. Pino, L.Z.; Solari, R.B.; Siquier, S.; Yépez, M.M.; SáEZ, A.E.; Estevez, L.A. Effect of Operating Conditions on Gas Holdup in Slurry Bubble Columns with A Foaming Liquid. Chem. Eng. Commun. 1992, 117, 367-382. [CrossRef]

39. Identification of Flow Regime in A Bubble Column Reactor with A Combination of Optical Probe Data and Machine Learning Technique | Elsevier Enhanced Reader. Available online: https://reader.elsevier.com/reader/sd/pii/S2590140019300309?token=91CB26F2EC2E42B75C44BCC0E459C6 277230581770BDBB3C225EC16B69C9FD1605ECA89BAD3911323176B735259AE471 (accessed on 11 October 2019).

40. Hyndman, C.L.; Larachi, F.; Guy, C. Understanding gas-phase hydrodynamics in bubble columns: A convective model based on kinetic theory. Chem. Eng. Sci. 1997, 52, 63-77. [CrossRef]

41. Krishna, R.; De Swart, J.W.A.; Ellenberger, J.; Martina, G.B.; Maretto, C. Gas Holdup in Slurry Bubble Columns: Effect of Column Diameter and Slurry Concentrations. AIChE J. 1997, 43, 311-316. [CrossRef]

42. Besagni, G.; Inzoli, F.; Ziegenhein, T. Two-Phase Bubble Columns: A Comprehensive Review. ChemEngineering 2018, 2, 13. [CrossRef]

43. Ruzicka, M.; Večeř, M.; Orvalho, S.; Drahos, J. Effect of surfactant on homogeneous regime stability in bubble column. Chem. Eng. Sci. 2008, 63, 951-967. [CrossRef] 
44. Besagni, G.; Inzoli, F.; Ziegenhein, T.; Lucas, D. Computational Fluid-Dynamic modeling of the pseudo-homogeneous flow regime in large-scale bubble columns. Chem. Eng. Sci. 2017, 160, 144-160. [CrossRef]

45. Guédon, G.R.; Besagni, G.; Inzoli, F. Prediction of gas-liquid flow in an annular gap bubble column using a bi-dispersed Eulerian model. Chem. Eng. Sci. 2017, 161, 138-150. [CrossRef]

46. Deshpande, S.S.; Kar, K.; Pressler, J.; Tebeka, I.; Martins, B.; Rosenfeld, D.; Biggs, J. Mass transfer estimation for bubble column scale up. Chem. Eng. Sci. 2019, 205, 350-357. [CrossRef]

47. Besagni, G.; Gallazzini, L.; Inzoli, F. On the scale-up criteria for bubble columns. Petroleum 2019, 5, 114-122. [CrossRef]

48. Sun, T.-Y.; Faeth, G.M. Structure of turbulent bubbly jets-I. Methods and centerline properties. Int. J. Multiph. Flow 1986, 12, 99-114. [CrossRef]

49. Sun, T.-Y.; Faeth, G.M. Structure of turbulent bubbly jets-II. Phase property profiles. Int. J. Multiph. Flow 1986, 12, 115-126. [CrossRef]

50. Iguchi, M.; Okita, K.; Nakatani, T.; Kasai, N. Structure of turbulent round bubbling jet generated by premixed gas and liquid injection. Int. J. Multiph. Flow 1997, 23, 249-262. [CrossRef]

51. Lima, D.D.; Lima Neto, I.E. Effect of Nozzle Design on Bubbly Jet Entrainment and Oxygen Transfer Efficiency. J. Hydraul. Eng. 2018, 144. [CrossRef]

52. Di Nunno, F.; Pereira, F.A.; de Marinis, G.; Di Felice, F.; Gargano, R.; Granata, F.; Miozzi, M. Two-Phase PIV-LIF Measurements in a Submerged Bubbly Water Jet. J. Hydraul. Eng. 2019, 145. [CrossRef]

53. Peng, G.; Oguma, Y.; Shimizu, S. Numerical simulation of unsteady cavitating jet by a compressible bubbly mixture flow method. IOP Conf. Ser. Earth Environ. Sci. 2018, 163. [CrossRef]

54. Nedeltchev, S.; Schumpe, A. A New Approach for the Prediction of Gas Holdup in Bubble Columns Operated under Various Pressures in the Homogeneous Regime. J. Chem. Eng. Jpn. 2008, 41, 744-755. [CrossRef]

55. Guan, X.; Yang, N.; Li, Z.; Wang, L.; Cheng, Y.; Li, X. Experimental Investigation of Flow Development in Large-Scale Bubble Columns in the Churn-Turbulent Regime. Ind. Eng. Chem. Res. 2016, 55, 3125-3130. [CrossRef]

56. Guan, X.; Gao, Y.; Tian, Z.; Wang, L.; Cheng, Y.; Li, X. Hydrodynamics in bubble columns with pin-fin tube internals. Chem. Eng. Res. Des. 2015, 102, 196-206. [CrossRef]

57. Shah, Y.T.; Kelkar, B.G.; Godbole, S.P.; Deckwer, W.-D. Design parameters estimations for bubble column reactors. AIChE J. 1982, 28, 353-379. [CrossRef]

58. Baird, M.H.I. Bubble column reactors. By W.-D. Deckwer, Wiley, New York, 1991. AIChE J. 1992, $38,1305$. [CrossRef]

59. Fan, L.-S.; Matsuura, A.; Chern, S.-H. Hydrodynamic characteristics of a gas-liquid-solid fluidized bed containing a binary mixture of particles. AIChE J. 1985, 31, 1801-1810. [CrossRef]

60. Lestinsky, P.; Vayrynen, P.; Vecer, M.; Wichterle, K. Hydrodynamics of Airlift Reactor with Internal Circulation Loop: Experiment vs. CFD Simulation. Procedia Eng. 2012, 42, 892-907. [CrossRef]

61. Prończuk, M.; Bizon, K.; Grzywacz, R. Experimental investigations of hydrodynamic characteristics of a hybrid fluidized bed airlift reactor with external liquid circulation. Chem. Eng. Res. Des. 2017, 126, 188-198. [CrossRef]

62. Benyahia, F.; Jones, L. Scale Effects on Hydrodynamic and Mass Transfer Characteristics of External Loop Airlift Reactors. J. Chem. Technol. Biotechnol. 1997, 69, 301-308. [CrossRef]

63. Dursun, G.; Akosman, C. Gas-liquid interfacial area and mass transfer coefficient in a co-current down flow contacting column. J. Chem. Technol. Biotechnol. 2006, 81, 1859-1865. [CrossRef]

64. Wilkinson, P.M.; Spek, A.P.; Dierendonck, L.L.V. Design parameters estimation for scale-up of high-pressure bubble columns. AIChE J. 1992. [CrossRef]

65. Wang, T.; Wang, J.; Jin, Y. Slurry Reactors for Gas-to-Liquid Processes: A Review. Ind. Eng. Chem. Res. 2007, 46, 5824-5847. [CrossRef]

66. Siegel, M.H.; Merchuk, J.C. Mass transfer in a rectangular air-lift reactor: effects of geometry and gas recirculation. Biotechnol. Bioeng. 1988, 32, 1128-1137. [CrossRef]

67. Gouveia, E.R.; Hokka, C.O.; Badino, A.C., Jr. The effects of geometry and operational conditions on gas holdup, liquid circulation and mass transfer in an airlift reactor. Braz. J. Chem. Eng. 2003, 20, 363-374. [CrossRef] 
68. Mießner, U.; Kück, U.D.; Dujardin, V.; Heithoff, S.; Räbiger, N. Correlation for kLa Prediction of Airlift Loop Reactors Including the Gas Phase Residence Time Effect. Chem. Eng. Technol. 2015, 38, 2002-2010. [CrossRef]

69. Zuber, N.; Findlay, J.A. Average Volumetric Concentration in Two-Phase Flow Systems. J. Heat Transf. 1965, 87, 453-468. [CrossRef]

70. Hewitt, G.F. The Flow of Complex Mixtures in Pipes. By G.W. Govier and K. Aziz Van Nostrand Reinhold 1972. 792 pp. £17.65. J. Fluid Mech. 1974, 65, 825-827. [CrossRef]

71. Hibiki, T.; Ishii, M. Distribution parameter and drift velocity of drift-flux model in bubbly flow. Int. J. Heat Mass Transf. 2002, 45, 707-721. [CrossRef]

72. Kawanishi, K.; Hirao, Y.; Tsuge, A. An experimental study on drift flux parameters for two-phase flow in vertical round tubes. Nucl. Eng. Des. 1990, 120, 447-458. [CrossRef]

73. Hibiki, T.; Ishii, M. One-dimensional drift-flux model and constitutive equations for relative motion between phases in various two-phase flow regimes. Int. J. Heat Mass Transf. 2003, 46, 4935-4948. [CrossRef]

74. Ulbrich, R. Identyfikacja przepływu dwufazowego gaz-ciecz. In Studia i Monografie WSI w Opolu z.32; WSI: Opole, Poland, 1989.

75. Chaali, M.; Naghdi, M.; Brar, S.K.; Avalos-Ramirez, A. A review on the advances in nitrifying biofilm reactors and their removal rates in wastewater treatment. J. Chem. Technol. Biotechnol. 2018, 93, 3113-3124. [CrossRef]

76. Kalenik, M.; Wichowski, P.; Morawski, D. Skuteczność napowietrzania wody w aeratorze rurowym wypełnionym pierścieniami Białeckiego. Rynek Instal. 2016, 12. [CrossRef]

77. Hosseiny, S.H. Modelling of organic removal in a moving bed biofilm reactor (MBBR). Sci. Iran. 2002, 9, 53-58.

78. Andreottola, G.; Foladori, P.; Ragazzi, M.; Tatàno, F. Experimental comparison between MBBR and activated sludge system for the treatment of municipal wastewater. Water Sci. Technol. 2000, 41, 375-382. [CrossRef]

79. Kruszelnicka, I.; Kramarczyk, D.G.; Poszwa, P.; Stręk, T. Influence of MBBR carriers' geometry on its flow characteristics. Chem. Eng. Process. Process Intensif. 2018, 130, 134-139. [CrossRef]

80. Deckwer, W.-D.; Louisi, Y.; Zaidi, A.; Ralek, M. Hydrodynamic Properties of the Fischer-Tropsch Slurry Process. Ind. Eng. Chem. Process Des. Dev. 1980, 19, 699-708. [CrossRef]

81. Besagni, G.; Deen, N.G. Aspect ratio of bubbles in different liquid media: A novel correlation. Chem. Eng. Sci. 2019, 115383. [CrossRef]

82. Mudde, R.F.; Groen, J.S.; Van Den Akker, H.E.A. Liquid velocity field in a bubble column: LDA experiments. Chem. Eng. Sci. 1997, 52, 4217-4224. [CrossRef]

83. Libra, J.A.; Schuchardt, A.; Sahlmann, C.; Handschag, J.; Wiesmann, U.; Gnirss, R. Comparison of the efficiency of large-scale ceramic and membrane aeration systems with the dynamic off-gas method. Water Sci. Technol. J. Int. Assoc. Water Pollut. Res. 2002, 46, 317-324. [CrossRef]

84. Öztürk, S.S.; Schumpe, A.; Deckwer, W.-D. Organic liquids in a bubble column: Holdups and mass transfer coefficients. AIChE J. 1987, 33, 1473-1480. [CrossRef]

85. Letzel, H.M.; Schouten, J.C.; Krishna, R.; van den Bleek, C.M. Gas holdup and mass transfer in bubble column reactors operated at elevated pressure. Chem. Eng. Sci. 1999, 54, 2237-2246. [CrossRef]

86. Kang, Y.; Cho, Y.J.; Woo, K.J.; Kim, S.D. Diagnosis of bubble distribution and mass transfer in pressurized bubble columns with viscous liquid medium. Chem. Eng. Sci. 1999, 54, 4887-4893. [CrossRef]

87. Vandu, C.O.; Krishna, R. Volumetric mass transfer coefficients in slurry bubble columns operating in the churn-turbulent flow regime. Chem. Eng. Process. Process Intensif. 2004, 43, 987-995. [CrossRef]

(C) 2020 by the authors. Licensee MDPI, Basel, Switzerland. This article is an open access article distributed under the terms and conditions of the Creative Commons Attribution (CC BY) license (http://creativecommons.org/licenses/by/4.0/). 